\title{
THE EVOLUTION AND DISPERSAL OF THE
} GRASSLAND LEAFHOPPER GENUS EXITIANUS, WITH KEYS TO THE OLD WORLD SPECIES (CICADELLIDAE : HEMIPTERA)

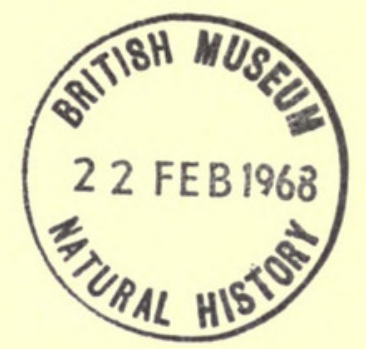

BY

\section{H. H. ROSS}

Illinois Natural History Survey, Urbana

$$
\text { Pp. I-30; } 82 \text { Text-figures }
$$

\author{
BULLETIN OF \\ THE BRITISH MUSEUM (NATURAL HISTORY) \\ ENTOMOLOGY \\ Vol. 22 No. I \\ LONDON : 1968
}


THE BULLETIN OF THE BRITISH MUSEUM (NATURAL HISTORY), instituted in I949, is issued in five series corresponding to the Departments of the Museum, and an Historical series.

Parts will appear at irregular intervals as they become ready. Volumes will contain about three or four hundred pages, and will not necessarily be completed within one calendar year.

In I965 a separate supplementary series of longer papers was instituted, numbered serially for each Department.

This paper is Vol. 22, No. I of the Entomological series. The abbreviated titles of periodicals cited follow those of the World List of Scientific Periodicals.

World List abbreviation :

Bull. Br. Mus. nat. Hist. (Ent.).

(C) Trustees of the British Museum (Natural History) 1968 


\title{
THE EVOLUTION AND DISPERSAL OF THE GRASSLAND LEAFHOPPER GENUS EXITIANUS, WITH KEYS TO THE OLD WORLD SPECIES (CICADELLIDAE : HEMIPTERA)*
}

\author{
By H. H. ROSS
}

CONTENTS

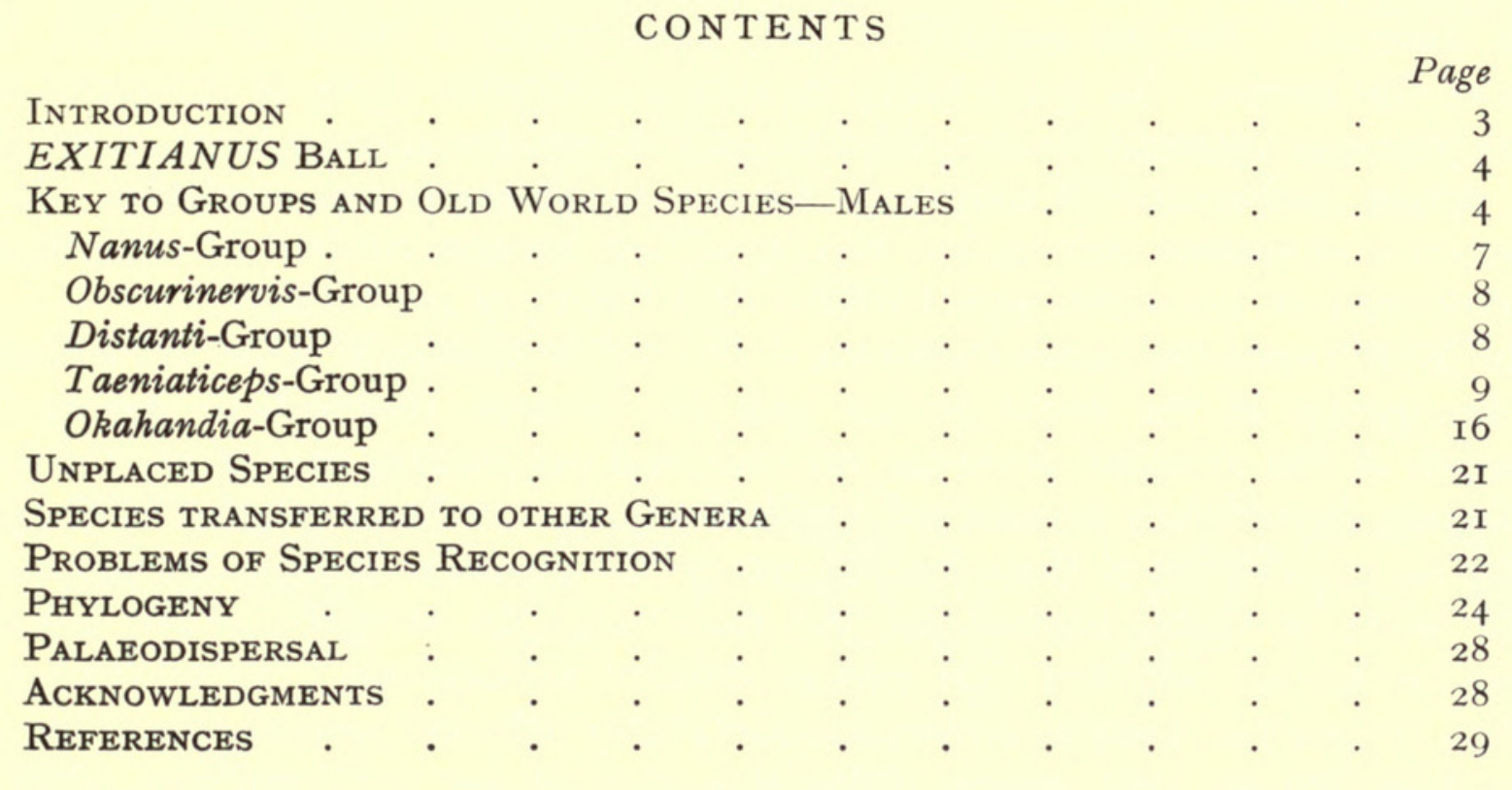

S Y NOPSIS

Keys and illustrations are presented for the identification of the five species-groups of Exitianus and for the identification of the species occurring in the Old World, the latter including seventeen species, nine new to science. Synonymy is included for the described Old World species plus a brief synopsis of their distribution. The phylogenetic relationships are adduced for the world fauna. When geographic distribution is compared with the postulated family tree there are strong indications that the genus evolved primarily in Africa with an ancient dispersal to the Americas and more recent dispersals to the Oriental and Australian regions.

\section{INTRODUCTION}

Among the most widespread and frequently the most abundant species of grassland leafhoppers are the moderately large tawny forms comprising the genus Exitianus, a member of the subfamily Deltocephalinae. This genus differs from related forms in having only a small number of apical, stout setae on the male pygofer; the female has a relatively long ovipositor extending conspicuously beyond the last dorsal segment. These characters are shared only by the presumably sister genus Nephotettix, readily differentiated from Exitianus by having the crown sharply ridged where it meets the face, and in being opaque green with various black markings.

* This work was supported in part by a research grant from the National Science Foundation, U.S.A. 
Based on similarities of male and female genitalia, Exitianus and Nephotetiix are probably most closely related to Doratura and its allies; the entire complex can be segregated as a grass-feeding tribe, the Doraturini.

On every continent at least one common form of Exitianus has a conspicuous black band across the top of the head. So similarly coloured are these forms that considerable difference of opinion has existed concerning the number of species involved. The same difference has been expressed concerning the number of species occurring on the same continent. DeLong \& Hershberger (I947) segregated eleven American species on the basis of colour and the number and position of the large pygofer spines. Linnavuori (I959) added a few more segregates from South America. No one appears to have undertaken a study of the Old World fauna of this genus. An opportunity in I 964 to examine types of the genus at the British Museum (Natural History) and Stockholm and to see large series of specimens from Africa, India, and Madagascar led me to attempt such a study. As new characters and species were found, the possibility became evident of reconstructing the phylogeny of the entire genus with a high degree of probability.

This paper treats the genus Exitianus in the following topical order: (I) a diagnosis and description of the world groups and the Eastern Hemisphere species, (2) a discussion of the peculiar problems encountered concerning species distinctions in the Eastern Hemisphere populations, (3) a derivation of the phylogeny of the genus, and (4) an application of these hypotheses to the question of its palaeodispersal.

This study is based entirely on the male sex. In several species, associated females are known but they have proven difficult to diagnose. Sexual dimorphism in colour is common, females of certain indubitably different species appear identical, and certain females that appear distinctive have as yet not been associated with males. In the face of these circumstances it appears that our present knowledge of Exitianus females does not lend itself to either keys or diagnoses of worthwhile predictive value.

\section{EXITIANUS Ball}

Exitianus Ball, I929:5. Type-species: Cicadula obscurinervis Stål.

Mimodrylix Zachvatkin, I935 : I08. Type-species: Athysanus capicola Stål.

Body usually about 4-5 mm. long. Colour chiefly tawny with various patterns of brown or black. Head only moderately produced (Text-figs. I-I4), the crown rounding into the face. Wings elongate and having typical leafhopper venation. Male pygofer having from two to six large dark or black spines along apical margin and only one or two other conspicuous spines. Aedeagus having an articulation between shaft and base, the shaft relatively simple in structure. Female ovipositor extending a considerable distance beyond abdominal tergites.

Distribution. Recorded from all continents except Antarctica.

\section{Key to Groups and Old World Species-Males}


2 (I) Pygofer having four to six apical brown or black spines (Text-fig. I5)

nanus-group 5

Pygofer having two or three apical brown or black spines (Text-figs. I9, 2I) . 3

3 (2) Dorsal margin of aedeagus with only a slight, irregular concavity at apex (Text-fig. 20) . . . . . . . . obscurinervis-group

Dorsal margin of aedeagus with a large arcuate concavity at apex (Text-fig. 22) 4

4 (3) Spine 2 of pygofer as long and slender as spine I (Text-fig. 2I)

Spine 2 of pygofer much shorter than and thicker than spine I (Text-fig. 24)

taeniaticeps-group

NANUS-Group

5 (2) Known only from one widespread Old World species

nanus (p. 7)

\section{OBSCURINERVIS-GROUP}

6 (3) Known from several New World species not treated further here. For diagnostic treatments see DeLong \& Hershberger (I947) and Linnavuori (I959).

\section{DIST ANTI-GROUP}

7 (4) Known only from one African species

distanti (p. 8)
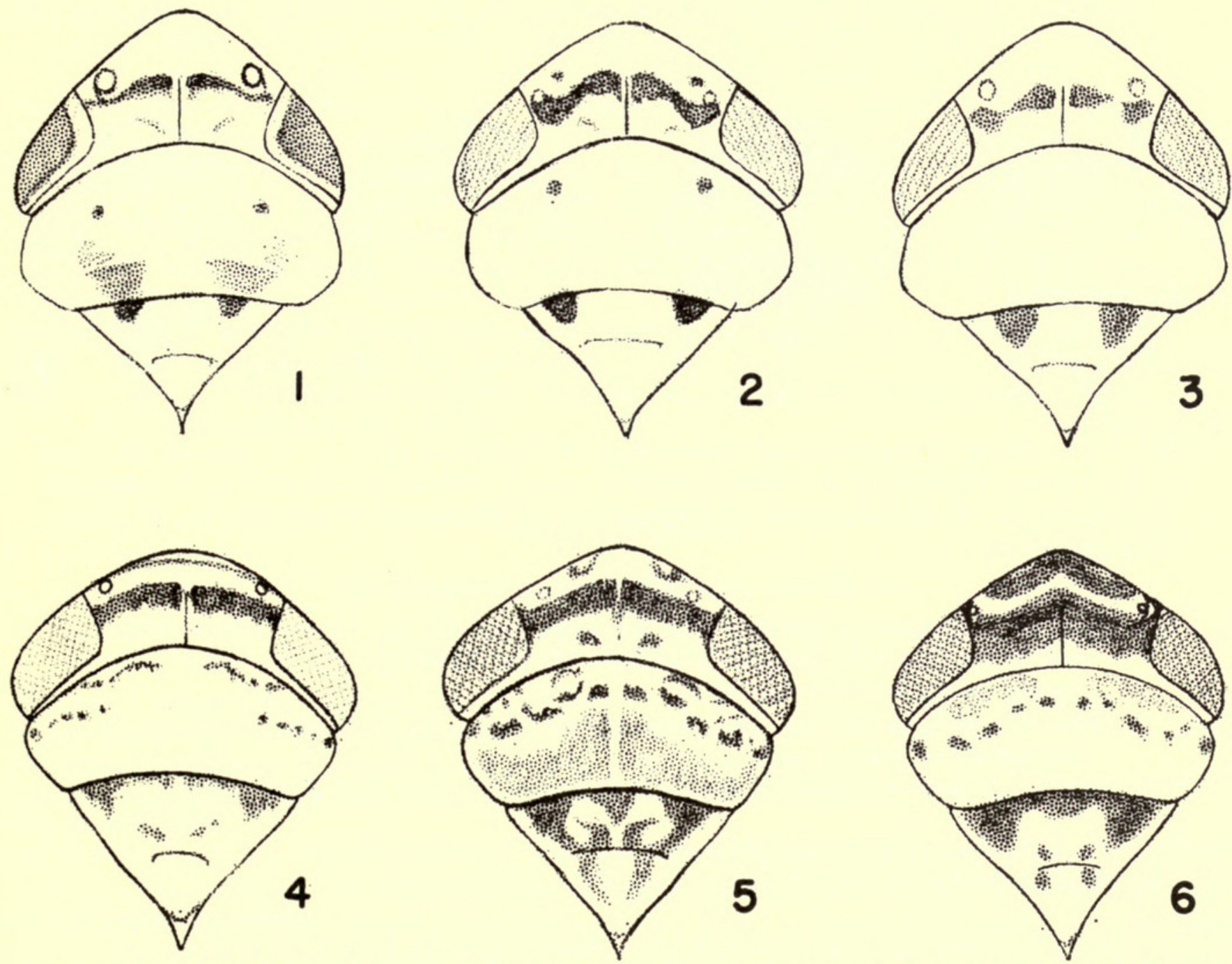

Figs. I-6. Head, pronotum and mesonotum of Exitianus spp. I, E. nanus (India); 2, same, dark form (Okahandia, Rhodesia); 3, same, light form (Okahandia, Rhodesia); 4, E. okahandia (holotype); 5. E. turneri (holotype); 6, E. natalensis (holotype). 


\section{TAENI ATICEPS-GRouP}

8 (4) Socket of spine 2 of pygofer almost contiguous with that of spine I (Text-fig. 23); head with extensive dark markings (Text-fig. I3)

kilimanus (p. I6)

Socket of spine 2 a considerable distance from that of spine I (Text-fig. 24); head variously marked .

9 (8) Spine 2 of pygofer only slightly asymmetrical (Text-figs. 64,65 ); aedeagal shaft tapering almost uniformly from base to gonopore (Text-fig. 33)

attenuatus (p. Io)

Spine 2 of pygofer markedly twisted or bent at tip (Text-figs. 24,26 ); aedeagal shaft either parallel-sided, or enlarged near gonopore, or markedly constricted at base of dorsal points
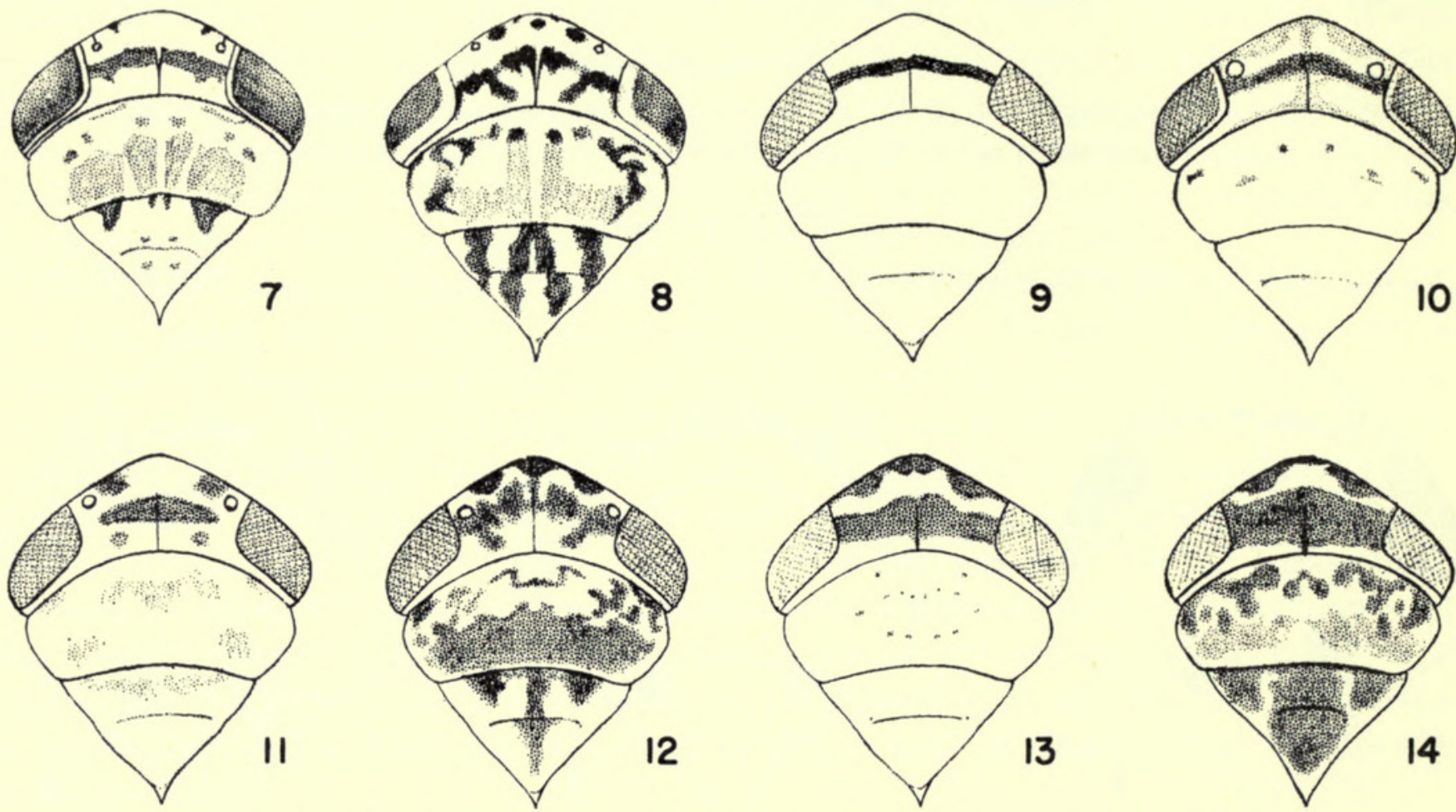

Figs. 7-I4. Head, pronotum and mesonotum of Exitianus spp. 7, E. picatus (Mexico; 8, E. exitiosus (Illinois); 9, E. indicus 우 (China); ro, E. indicus (holotype); II, E. coronatus (holotype); I2, E. ootacamundus (holotype); I3, E. kilimanus (holotype); I4, E. greensladei (paratype).

Io (9) Shaft of aedeagus as thick as in Text-figs. 25, 28, 30, 3I, its paired dorsal points usually well separated at base as in Text-fig. 27, its apex long, slender and markedly curved .

Shaft of aedeagus thinner (Text-figs. 34-36, 39-5I), or its dorsal points nearly contiguous at base

I I (Io) Dorsum of head yellow with rigidly defined black spots as in Text-fig. II

coronatus (p. I4)

Dorsum of head otherwise (Text-figs. Io, I2)

I 2 (I I) Dark markings on top of head as extensive as in Text-fig. I2

Dark markings on top of head chiefly a single, arcuate, dark line (Text-fig. ro),

ootacamundus (p. I4) sometimes with additional light brown suffusions

indicus (p. 12 )

I3 (Io) Dorsal profile of shaft with a slight notch on which dorsal points are situated (Text-figs. $34-36,39-42,47$ ) . 
Dorsal profile of shaft with no indication of a notch where dorsal points are situated (Text-figs. 43-46, 48-5I)

I4 (I3) Profile of aedeagal shaft markedly angulate below gonopore, gonopore opening very long (Text-fig. 34) .

pondus (p. II)

Either profile of aedeagal shaft rounded below gonopore (Text-figs. 39-42) or gonopore opening much shorter (Text-figs. 35, 47)

I 5 (I4) Either aedeagal shaft slightly to moderately flared before gonopore (Text-figs. 39-4I) or dorsal points close to base of shaft (Text-fig. 42) taeniaticeps (p. II)

Aedeagal shaft not flared and dorsal points as far from base of shaft as shown in Text-figs. $35,36,47$.

frontalis (p. I 2 )

I6 (I3) Head with extensive dark markings (Text-fig. I4) . . greensladei (p. I6)

- $\quad$ Head with only a dark arcuate band, as in Text-fig. Io _ . . . . . . $\quad$ I7

I7 (I6) Profile of aedeagal shaft with lateral ridge close to margin and apical excavation forming an obtuse angle with body of shaft (Text-figs. $4^{8-5} \mathrm{I}$ )

Profile of aedeagal shaft with lateral ridge closer to central line of shaft and plebeius (p. I5) apical excavation forming nearly a right angle with body of shaft (Textfigs. 43-45) .

mucronatus (p. I4)

\section{OKAHANDIA-GROUP}

I8 (I) Apex of pygofer forming an upturned, fingerlike tip bearing one extremely stout, dorsally projecting spine and sometimes another much more slender spine (Text-figs. 6o, 63); apex of style scarcely widened (Text-fig. 58) . . .

Apex of pygofer wider, not upturned, and bearing two fairly stout spines (Text-figs. 52, 56); apex of style greatly widened (Text-figs. 54, 55) . .

I9 (I8) Apex of pygofer bearing only one spine, this spine wider than pygofer tip (Text-fig. 63); profile of aedeagus wider (Text-fig. 62)

zuluensis (p. I8)

Apex of pygofer bearing a slender seta mesad of large one, the latter narrower than pygofer tip (Text-fig. 6o); profile of aedeagus narrower (Text-fig. 59)

natalensis (p. 20)

20 (I8) Style markedly shorter than plate (Text-fig. 55); costal area of front wing not forming a conspicuous light stripe . . . . . okahandia (p. I7)

Style projecting beyond plate (Text-fig. 54); costal area of front wing forming a conspicuous light stripe

turneri (p. I7)

\section{NANUS-GROUP}

\section{Exitianus nanus (Distant) comb. $\mathbf{n}$.}

(Text-figs. I, 2, 3, I5, I6, I7, I8, 76)

Athysanus nanus Distant, $1908: 345$. India.

Athysanus insularis Distant, I909: 47. Amirante Is. syn. n.

Athysanus simillimus Matsumura, I914: I85. Formosa. syn. n.

Euscelis vulnevans Bergevin, 1925:42. Southern Algeria. syn. n.

This is the most widespread Old World species of the genus, occurring throughout Africa, Asia Minor, southern Asia, Formosa, islands in the Indian Ocean, and Australia. The dorsal head markings may be faint or form dark spots or crescentic bars. Well-marked specimens show considerable geographic variation. In specimens from Asia, the dark markings usually form a solid curved arc interrupted on the meson (Text-fig. I, as in the type of namus); specimens from the southern half 
of Africa invariably have each half of the mark either narrowed in the middle (Textfig. 2) or completely pinched off into a pair of black spots (Text-fig. 3). In specimens from Asia Minor and North Africa, the dark marks intergrade between the two darker types and occasionally these intergradations are encountered in Asian material also.

The type male of insularis (Text-fig. I5) has pygofer spines 2-4 relatively slender; males from Tanzania have them slightly shorter and more robust (Text-fig. I7); specimens from Johannesburg, Republic of South Africa, have a mixture of slender and stouter spines on each specimen, and sometimes five or six spines on a side (if so, usually not the same number on both sides). The spination of the pygofer therefore mirrors the variation found in the colour pattern.

I have studied the types of nanus Distant and insularis Distant but not those of simillimus Matsumura and vulnerans Bergevin. The latter two species I am placing on the basis of illustrations by Ishihara (I954, fig. 5) and illustrations in the original description, respectively.

The female seventh sternite is characterized by the bi-emarginate apical margin and the slightly bowed mesal area (Text-fig. 76).

\section{OBSCURINERVIS-GROUP}

(Text-figs. 7, 8, I9, 20)

The members of this American group of species are remarkably homogeneous in shape of aedeagus and pygofer, and in spines I and 2 of the pygofer. In all members spine 3 is absent, in most members spine 4 is present, and in occasional individuals of the latter species an additional spine 5 may be present on one or both sides of the capsule. The females exhibit a considerable number of inter-specific differences in the shape of the apical margin of the seventh sternite.

DeLong \& Hershberger (I947) and Linnavuori (I959) deal with eleven and seven American species, respectively. I am making no attempt to correlate the two accounts pending the availability of longer tropical series needed to establish the associations of the two sexes and possible synonymy.

\section{DIST ANTI-GROUP}

\section{Exitianus distanti sp. $\mathrm{n}$.}

(Text-figs. 2I, 22)

6. Length $4 \mathrm{~mm}$. Colour of dorsum pale greenish yellow, face the same but with arcuate dark lines, venter of thorax and abdomen almost black, legs with coxae black, the remaining segments tawny with dark streaks. Dorsum of head proportioned as in Text-fig. 9, without any trace of arcuate banding. General structure typical for genus. Pygofer having only setae I and 2, both of them straight and slender (Text-fig. 2I). Aedeagus with shaft elongate, slender, its apex arcuately incised, as seen from lateral view, and the shaft bearing a pair of dorsal projections below middle (Text-fig. 22).

Holotype ô (in glycerine). [TANzania] Tanganyika: Ilonga, 28.vi.Ig62 ( $L$. Robertson). In B.M.(N.H.). 
Paratype. [TAnzania] Tanganyika: Ukirigiru, I $\widehat{0}$ (pinned, abdomen in glycerine), 27.iv. I96I, light trap. In B.M.(N.H.).

The two specimens have been preserved in alcohol, and the greenish cast may be due to the action of that preservative. This species forms a unique group all of its own, characterized by the possession of only spines I and 2 on the pygofer, and the long and slender spine 2 that is much like spine I. In all other known species having only spines I and 2, spine 2 is much thicker and more densely pigmented than spine $\mathrm{I}$.

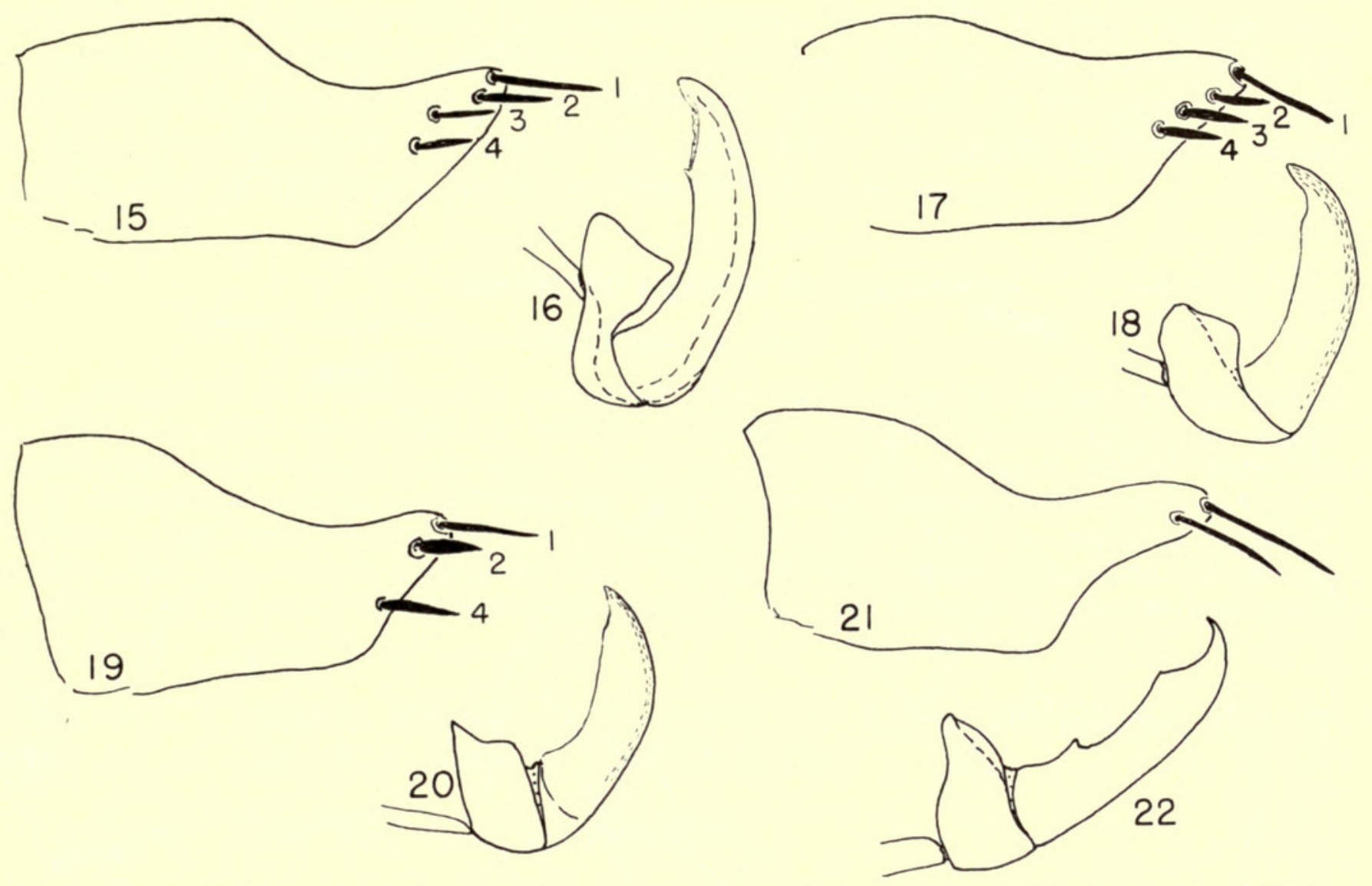

Figs. I 5-22. Male genital parts of Exitianus spp. I5, I6, E. nanus (holotype of insularis);

17, I8, E. nanus (Tanzania); 19, 20, E. exitiosus (Illinois); 21, 22, E. distanti (holotype);

I5, I7, I9, 2I, pygofer; I6, I8, 20, 22, aedeagus, lateral aspect.

\section{TAENIATICEPS-GROUP}

In this group the aedeagus has a well-defined preapical notch, a sharp, curved apex, and a pair of small, dorsal, sclerotized points; the pygofer usually possesses only spines I and 2 , of which spine $I$ is slender and elongate, and spine 2 is much shorter, black, and more or less twisted at the tip (Text-figs. 23, 24, 64, 65). In most species the vertex of the head has only a single transverse-arcuate black band (Text-fig. 9), often with suffusions of paler brown (Textfig. Io); in a few the vertex is darker (Text-fig. I2) or has a different pattern of banding (Textfig. II).

In those species for which the two sexes are associated (indicus, taeniaticeps, frontalis, and plebeius), the female eighth sternite has a narrow, V-shaped apical incision bordered with darker colouring (Text-fig. 69). In the case of mucronatus, 
pondus, and several other species, females of the same type were present from the same or nearby localities. It seems likely that females of all members of this group share this distinctive configuration of the eighth sternite. The unassociated female type of capicola (Stål) (Text-fig. 70) can therefore at present be assigned to this group but not definitely to any species. As explained below under indicus Distant, geographic location gives a clue as to the possible identity of fusconervosus (Mots.).
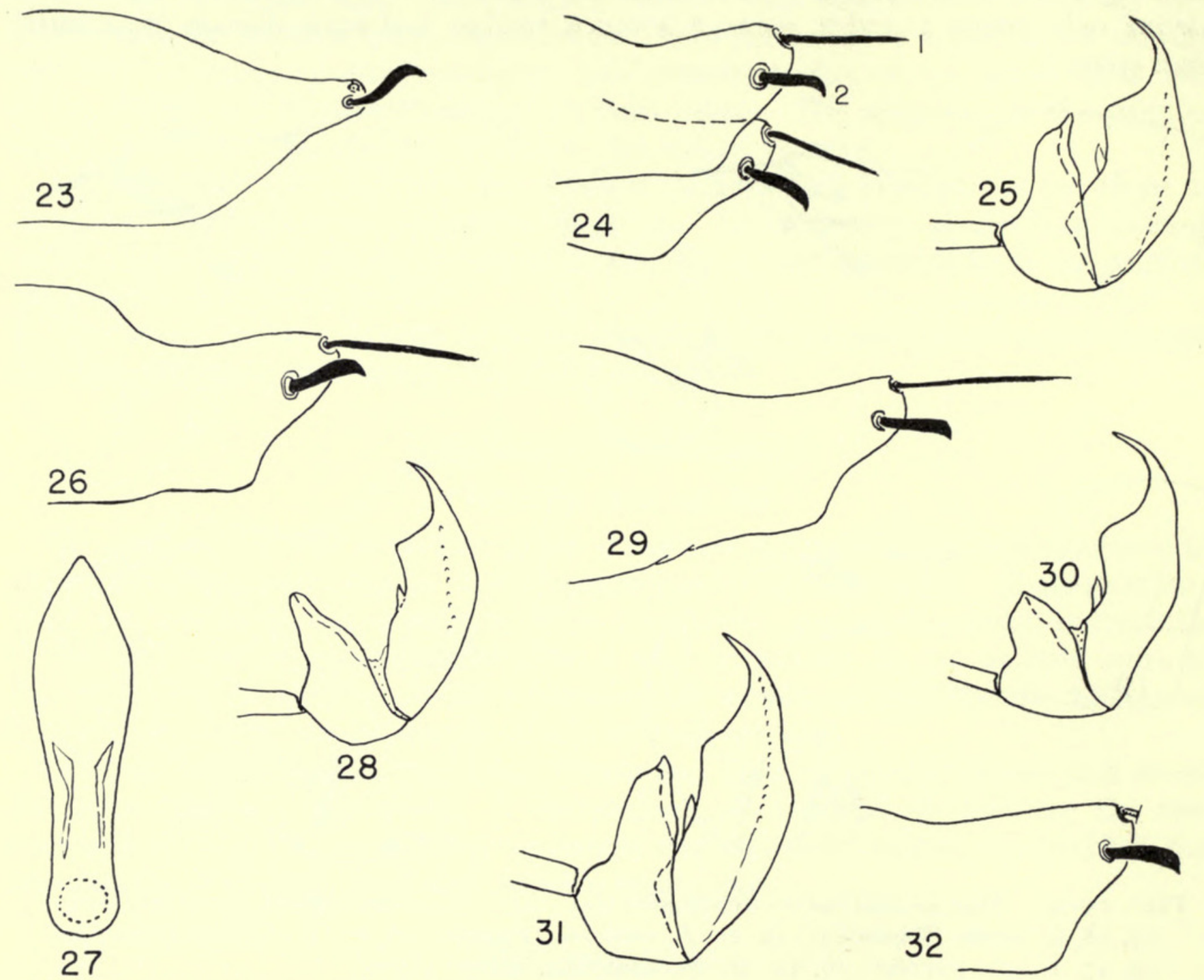

Figs. 23-32. Male genital parts of Exitianus spp. 23, E. kilimanus (holotype); 24, 25, E. ootacamundus (holotype); 26, 27, 28, E. indicus (type series); 29, 30, E. indicus (Ceylon); 3I, 32, E. coronatus (holotype). 23, 24, 26, 29, 32, pygofer; 25, 28, 30, 31, aedeagus, lateral aspect; 27, aedeagus, posteroventral aspect.

\section{Exitianus attenuatus sp. $\mathrm{n}$.}

(Text-figs. 33, 64, 65, 66)

7. Length $4.5 \mathrm{~mm}$. Colour above and below tawny, with a thin arcuate black line across dorsum of head (as in Text-fig. 9) and frontal area of head and legs with small dark markings. General structure typical for genus. Pygofer with spines I and 2, or I, 2 and 3; spine I is long and slender, spine 2 or spines 2 and 3 are shorter, thicker, darker and very slightly asymmetrical at apex (Text-figs. 64, 65). Aedeagus with shaft tapering almost uniformly from base to 
gonopore, the portion beyond that slender and arcuately incised (Text-fig. 33); near the base of the shaft are a pair of dorsal points or projections that are finger-like, flared laterally, the two well separated at the base (Text-fig. 66).

Holotype ô (pinned, genitalia in glycerine). South Africa: Cape Province, Somerset East, xi.r930 (R. E. Turner). In B.M.(N.H.).

Paratype. Same data, I ô (pinned, genitalia in glycerine). In B.M.(N.H.).

Both type specimens have the pygofer spines somewhat damaged, but the remaining evidence indicates several interesting items: (I) spine I is long and slender; (2) spine 2 is only slightly asymmetrical (Text-figs. 64, 65), not approaching the bent condition (Text-figs. 23, 24, 26) of related species; and (3) the genetic control for spine 3 has not been completely lost. The latter two points warrant a serious consideration of this species as the most primitive of its group.

\section{Exitianus pondus sp. $\mathrm{n}$.}

(Text-figs. 34, 67)

o. Length $5 \mathrm{~mm}$. Colour tawny except for a fine dark arcuate line across anterior portion of vertex and a few dark marks on the face and legs. General structure typical for genus. Pygofer with spines I and 2 only, spine I long and slender, spine 2 deeper, shorter, almost jet black, and markedly asymmetrical (Text-fig. 67), the extreme tip slightly but definitely hooked ventrally. Aedeagus (Text-fig. 34) with profile of shaft wide at base and tapering slightly to gonopore, the apex with an arcuate incision occupying the apical third of the shaft and forming a long narrow apex sharply hooked at tip; near the base of the shaft is a prominent pair of dorsal points.

Holotype ô (pinned, abdomen in glycerine). S. Africa: Pondoland, Port St. John, I-9.vii.I923 (R. E. Turner). In B.M.(N.H.).

Paratypes. Same data, 2 ô. In B.M.(N.H.).

Three specimens that resemble the above types very closely but lack dorsal points at the base of the shaft are tentatively considered as this species but not included in the types, as follows: S. Africa: Zululand, Gingindhlovu, 2 ô, I5 .vi.I926 (R. E. Turner); MAdagascar: Morondova, forest south of Befasy, I o, i.I956 (R.P.).

\section{Exitianus taeniaticeps (Kirchbaum)}

(Text-figs. 37, 39-42, 7I)

Athysanus taeniaticeps Kirchbaum, I868:87. Messina, Syracuse.

I have not seen the type of this species, but the description fits perfectly the species here considered as taeniaticeps, which is the only species of the group so far identified from the circum-Mediterranean countries. Specimens from Iraq, Lebanon, Cyprus, France, and Libya are remarkably uniform, in contrast with other populations in the species, in having the dorsal points some distance from the base of the shaft (Text-figs. 39-4I). Males from Rhodesia, considered as this species, usually 
have these points almost at the base of the shaft (Text-fig. 42). Large series of males from central Sudan are much more variable in this character, completely bridging the morphological gap between the Mediterranean and Rhodesian populations.

This situation suggests that the Mediterranean and South African populations represent previously isolated segments of an ancestral population that became morphologically different, then were brought together by changing ecological conditions and have since formed an intermingled, freely-hybridizing population in at least the Sudan.

In a few Rhodesian males the apico-central corner of the pygofer is almost square (Text-fig. 37), in contrast to the sinuate condition normally found throughout other populations of the species (as indicated by the broken line in Text-fig. 37).

The illustrations of Ribaut (I952 : I38, figs. 245-249) undoubtedly refer to this species, although pygofer spine 2 is shown as straight rather than contorted at the tip. It should be noted that in Fig. 248 the shaft is folded into the socket so that the latter hides the real base of the shaft and the dorsal points of the shaft therefore erroneously appear to be basal.

\section{Exitianus frontalis (Distant) comb. n.}

(Text-figs. 35, 36, 47)

Athysanus frontalis Distant, 1917 : 317. Seychelles.

An extremely close relative of taeniaticeps, this species as here recognized is diagnosed by the uniformly thick shaft (Text-figs. 35, 36) in contrast with the slightly to markedly clavate shaft of taeniaticeps (Text-figs. 39-42). In frontalis the dorsal points of the shaft are some distance from the shaft's base, as sometimes occurs in Mediterranean specimens but not in South African specimens of taeniaticeps, suggesting that in the latter species there has been a displacement of this character in the southern part of Africa where both taeniaticeps and frontalis occur in the same area.

To date this species has been found in the Seychelles, Madagascar (Diego-Suarez, Montagne des Francais), and South Africa (Pondoland). It is interesting that the three specimens from Pondoland exhibit almost exactly the same range of variation in the aedeagal shaft as found in the two specimens illustrated from Madagascar. The male from the type series (Text-fig. 47) is a slender extreme, matched almost perfectly by a specimen from Pondoland in the Turner collection, B.M.(N.H.). I have studied the female type, in which the eighth sternite is notched as in other species of the group.

Exitianus indicus (Distant) comb. $\mathbf{n}$.

(Text-figs. 9, I0, 26-30, 69)

?Athysanus fusconervosus Motschulsky, 1863 : 97. Ceylon.

Athysanus indicus Distant, I908 : 344. India.

Athysanus atkinsoni Distant, I908: 345. India. syn. n. 


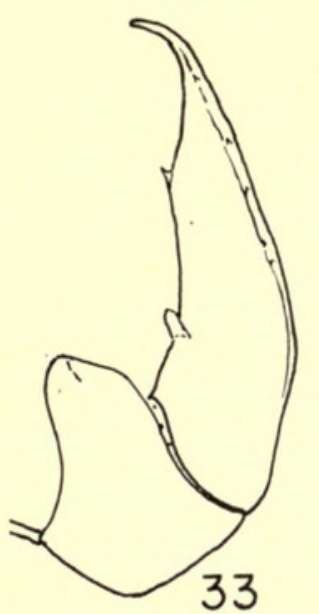

33

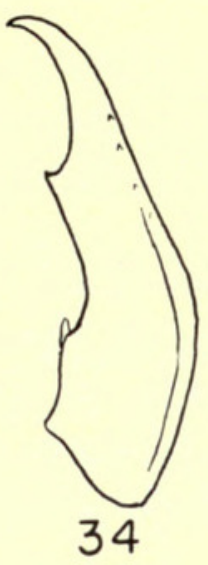

34

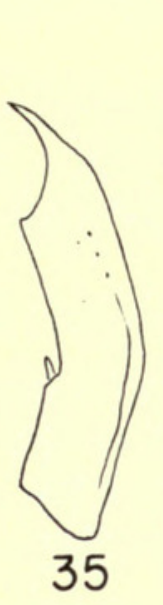

36

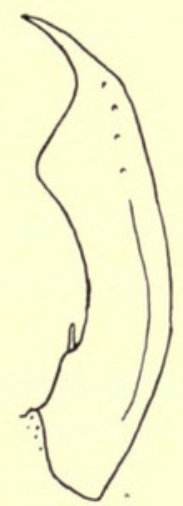

39

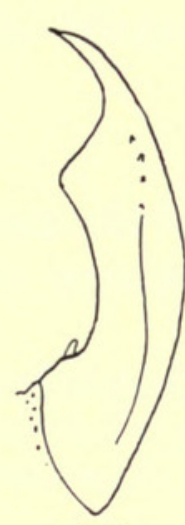

40
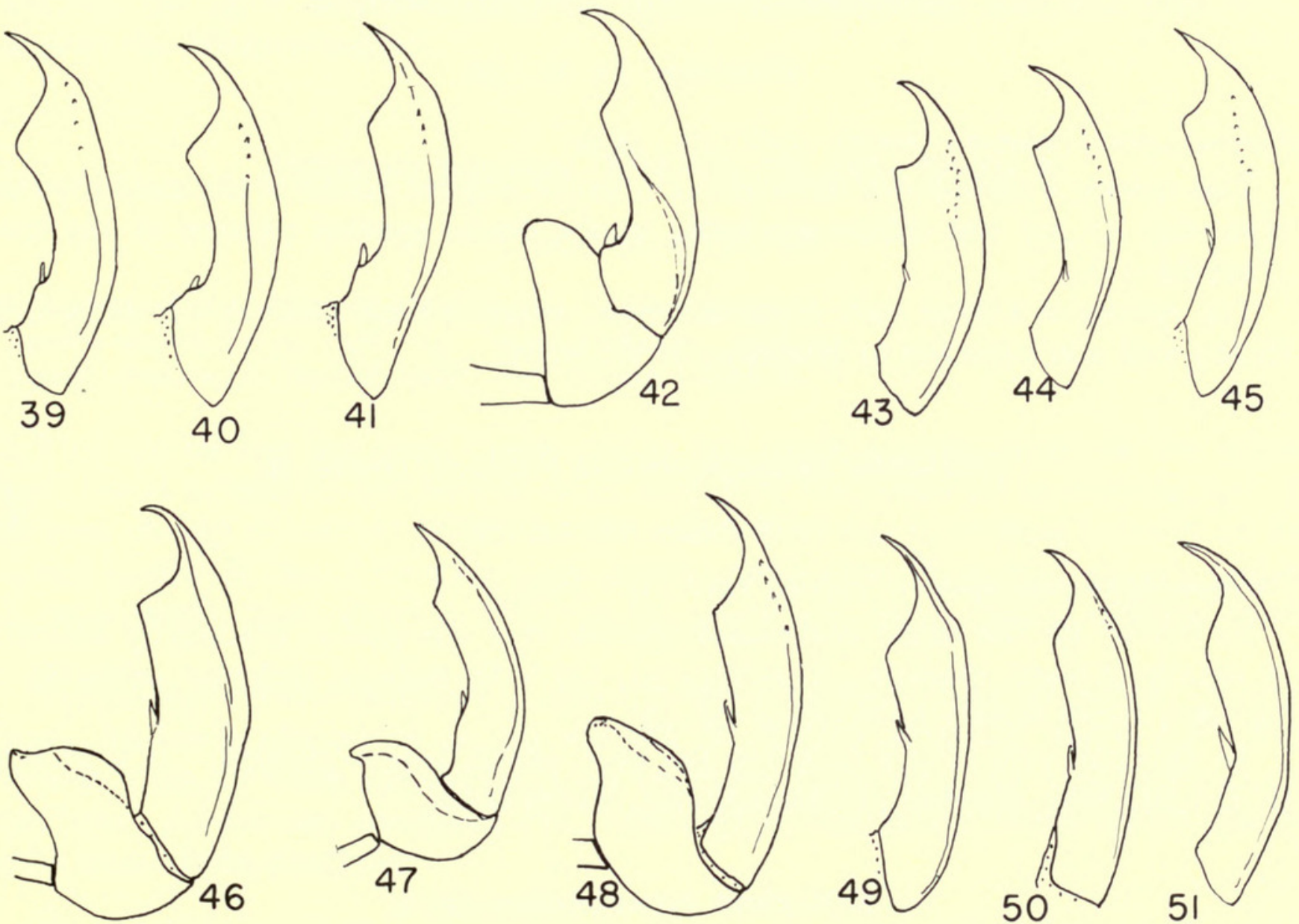

Figs. 33-5I. Male genital parts of Exitianus spp. 33, E. attenuatus (holotype); 34, E. pondus (holotype); 35, 36, E. frontalis (Madagascar); 37, E. taeniaticeps (Rhodesia); 38, E. frontalis (type series); 39, 40, 4I, E. taeniaticeps (Tripoli); 42, the same (Rhodesia); $43,44,45$, E. mucronatus (holotype and two paratypes, respectively); 46, E. greensladei (holotype); 47, E. frontalis (type lot); 48, E. plebeius (Queensland); 49, the same (paratype of plebeius); 50, the same (Samoan Is.); 5I, the same (homeotype of norrisi). 37, 38 , pygofer; all others, aedeagus or shaft only, lateral aspect. 
This is a pale species having a faint or thin, dark, transverse, arcuate band on the vertex. It has been taken at several localities in India (in great abundance at Kharagpur), Ceylon, Formosa, and Japan.

I have studied the female types of both Distant names. These are in B.M.(N.H.), bearing identical data 'Calcutta, Atkinson Col. 92.6.' The common type series of the two species contains several males that demonstrate the characters of this sex (Text-figs. 26-28).

There is a possibility that fusconervosus Motschulsky, described from the summit of Mt. Patannos, Ceylon, may apply to this species, which is the only one of the genus thus far recorded for the island, but the unavailability of the type mitigates against the use of its carrier name at the present time. Ishihara's illustrations of E. capicola (Stål), listed under Mimodrylix Zakhvatkin, undoubtedly apply to this species (Ishihara, I954: 6).

\section{Exitianus coronatus (Distant) comb. $\mathbf{n}$.}

(Text-figs. II, 3I, 32)

Phrynomorphus coronatus Distant, I918:52. India.

This species is remarkably like indicus in morphological details of the male genitalia (Text-figs. 3I, 32) but differs markedly in the dorsal spotted pattern of the head (Text-fig. II).

The species is known only from the type, which I have studied. It is in B.M. (N.H.) and was collected at Kumaon, N.W. India.

\section{Exitianus ootacamundus (Distant) comb. $\mathrm{n}$.}

(Text-figs. I2, 24, 25)

Phrynomorphus ootacamundus Distant, 1918:51. India.

As is true for the above-mentioned species, this one also is practically identical in details of male genitalia (Text-figs. 24, 25) with indicus, differing primarily in having a much darker head (Text-fig. I2).

To date the only known record is the type, which I have studied. It is in B.M. (N.H.) and was collected at Ootacamund, South India.

\section{Exitianus mucronatus sp. $\mathrm{n}$.}

(Text-figs. 43, 44, 45)

o. Length $4.5 \mathrm{~mm}$. Colour pale tawny except for a black arcuate band across the vertex, much as in Text-fig. 9, and a few pale marks on face and legs. General structure typical for genus. Pygofer with spines I and 2 only, spine I very long slender, spine 2 much shorter, asymmetrical, and slightly hooked at apex as in Text-fig. 37. Aedeagus with shaft moderately long and thick (Text-figs. 43-45), with an apical arcuate incision resulting in a sharp hooked tip; the dorsal points are minute and their bases do not interrupt the even contour of the dorsal surface. 
Holotype ô (pinned, abdomen in glycerine). Madagascar: Ft. Dauphin (R.P.). In collection of Madagascar Scientific Institute.

Paratypes. Madagascar: Ft. Dauphin, Tananarive, Bas Mangoky, Nosivola, Perinet, Monronova forest south of Befasy, Montagne des Francais and Andova, 28 o. In collections of Madagascar Scientific Institute, Illinois Natural History Survey and B.M.(N.H.).

This series of specimens appears to represent a distinctive and perhaps an endemic Madagascar species differing from plebeius in having a stouter aedeagal shaft whose ventral lateral ridges curve dorsally and disappear toward the apex. In Madagascar, mucronatus appears to displace taeniaticeps almost completely, although the latter species appears to be abundant in Madagascar at Mohali, lac Iconi, and one specimen has been taken from Rte de Fianarantsoa, Km. 334. These specimens of taeniaticeps are like the more massive Rhodesian type rather than the narrower type found around the Mediterranean.

\section{Exitianus plebeius (Kirkaldy) sp. rev., comb. $\mathrm{n}$.}

$$
\text { (Text-figs. }{ }^{8}{ }^{-5} \text { I, } 68 \text { ) }
$$

Nephotettix plebeius Kirkaldy, r906 : 331. Queensland.

Eutettix norrisi Evans, I938 : I4. West Australia. syn. n.

Euscelis transversus Metcalf, I946 : I22. Guam. syn. n.

This species has the same tawny colour and black arcuate stripe on the vertex as is found in indicus and several other species of the genus (as in Text-fig. 9). It is most closely related to frontalis, from which it differs in lacking a notch on the dorsal profile of the shaft where the dorsal spines arise (Text-figs. 48-5I), and to E. mucronatus, from which it differs in the longer and more slender aedeagal shaft.

The holotype $q$ and paratype $\delta$, which I have examined, are from Cairns, Queensland, Australia, deposited in the Bernice P. Bishop Museum, Honolulu. Both appear to be the same species and I am herewith designating the of paratype as the allotype. I have also examined the $\hat{\sigma}$ holotype of transversus, which agrees exactly with males from Australia.

Concerning norrisi, I am following the synonymy of Evans (I966). To date the only records of this species I have personally examined are from Australia, Guam, and Samoa. The records of capicola cited by Linnavuori (I960) from Fiji are based on females, but probably refer to this species. Previously this species has been confused with other species in the Old World having the same colour, and the Australian records have been labelled as capicola. The distinct, long shaft and the inconspicuous dorsal aedeagal spines indicate, however, that this species is different from those occurring on other continents. 


\title{
Exitianus greensladei sp. $\mathrm{n}$.
}

\author{
(Text-figs. I4, 46, 78)
}

๙. Length $4 \mathrm{~mm}$. Background colour tawny with many dark areas; vertex with a wide black arcuate band covering most of the area, face almost entirely black, the facial marks running up slightly over the edge of the vertex; exposed thorax with heavy black spots (Textfig. I4); legs and venter of body with irregular dark marks; membrane of wings almost hyaline, the veins bordered by dark brown striping. General structure typical for genus. Pygofer with only spines I and 2, spine I long and slender, spine 2 shorter, thicker, darker, and slightly hooked at apex, as in Text-fig. 24. Aedeagus with shaft long and slender (Text-fig. 46), the dorsal points minute and their bases below the dorsal contours.

Holotype $\hat{\sigma}$ (pinned, abdomen in glycerine). Solomon Islands: Guadalcanal, Kau Kau, I7.xi.I962, no. 2924 (P. Greenslade). In B.M.(N.H.).

Paratype. Same data, I ơ (pinned, abdomen not cleared). In B.M.(N.H.).

This heavily marked species is a close relative of plebeius, which it resembles in structure of genitalia and from which it differs primarily in the dark colour pattern. The two specimens of the type series are both markedly smaller (4 versus $5 \mathrm{~mm}$.) than any specimens of plebeius I have yet seen.

\section{Exitianus kilimanus(Jacobi) comb. $\mathbf{n}$.}

$$
\text { (Text-figs. I3, 23) }
$$

Phrynomorphus kilimanus Jacobi, I910: I3I. Kilimandjaro, Africa.

This species is readily distinguished by the twisted spine 2 of the pygofer and the very close proximity of the bases of spines I and 2 (Text-fig. 23). The head and pronotum are heavily marked with black (Text-fig. I3), much as in greensladei. The type $\hat{\sigma}$ (which I have seen) bears the collection data: Meru, 3,000-3,500 m Jan. (Sjostedt). Another female from the same locality on Mount Kilimandjaro bears a type label but a second female bearing a red 'Allotypus' label is evidently another species. I was not in the Stockholm Museum long enough to clear the genitalia of the type but the diagnostic position of the pygofer spines was readily visible on the dried specimen.

\section{OKAHANDIA-GROUP}

Among the extensive grass-inhabiting species collected in Africa by R. E. Turner, I found four species that form a distinctive group of Exitianus in which the plates are short and lack lateral spines, and the styles have the apex truncate and projecting nearly posteriorly, rather than being sharp and curved sharply laterally (Text-fig. 82 ) as is true of all other members of the genus. 


\title{
Exitianus okahandia sp. $\mathrm{n}$.
}

\author{
(Text-figs. $4,55,56,57,72$ )
}

o. Length $4 \mathrm{~mm}$. Colour tawny with the following black marks: a fairly narrow arcuate band on vertex, small black spots on pronotum, several black spots on scutellum (Text-fig. 4), plus markings on the face, legs, and venter. General structure typical for genus. Plates ovate, without lateral spines, and about as long as wide (Text-fig. 55), extending considerably beyond apex of styles. Styles with apex broadened and truncate (Text-fig. 55). Pygofer of usual shape for genus, with only spines I and 2, both symmetrical, spine 2 shorter, thicker, and darker than spine I (Text-fig. 56). Aedeagus moderately long, its apex with only a slight and inconspicuous incision (Text-fig. 57).

ㅇ. Length $5.5 \mathrm{~mm}$. Colour and general structure similar to male. Apex of eighth sternite slightly produced in middle, the segment often with a small dark spot on each side near the middle of the lateral half of the segment (Text-fig. 72).

Holotype $\hat{\sigma}$ (pinned, abdomen in glycerine). South Africa: Natal, Van Reenen, Drakensberg, I-22.i.I927 (R. E. Turner). In B.M.(N.H.).

Allotype ㅇ. Southwest Africa: Okahandja, I0-I6.ii.I928 (R. E. Turner). In B.M.(N.H.).

Paratypes. Same data as allotype + , 3 ô, 8 ㅇ, with inclusive dates 27.i-I 8 . iii. I $\hat{\delta}$, I $q$ in Illinois Natural History Survey collection, remainder in B.M.(N.H.).

Additional females that appear to belong to this species are from South AFrica: Cape Province, Queenstown; Transkei, Untata. [TAnzania] Tanganyika: Ukiriguru.

\section{Exitianus turneri sp. $\mathrm{n}$.}

(Text-figs. 5, 52, 53, 54, 73)

๙. Length $4.5 \mathrm{~mm}$. Colour tawny, head with a black arcuate band slightly interrupted at middle (Text-fig. 5), face with a narrow mesal stripe in addition to more lateral markings; legs with dark marks; tegmina with all veins pale brown except costal margin which is contrastingly cream coloured. General structure typical for genus. Pygofer moderately narrow at apex, which bears spines I and 2, both long and symmetrical, spine 2 thicker and shorter than spine I and with a marked crease at its base (Text-fig. 52). Plates short and obliquely truncate, without large lateral spines (Text-fig. 54). Style with flared apex, extending slightly beyond plate (Text-fig. 54). Aedeagus with shaft short and slightly sinuate (Text-fig. 53).

․ Length $5.5 \mathrm{~mm}$. Colour and general structure similar to male except for the median stripe on the face which is usually paler. Eighth sternite (Text-fig. 73) with a fairly deep broad cleft apically, and with a black oblique bar on each side almost at the apical margin.

Holotype $\hat{o}$ (pinned, abdomen in glycerine). South Africa: Pondoland, Port St. John, I-II.vi.I923 (R. E. Turner). In B.M.(N.H.).

Allotype +. South Africa: Zululand, Gingindhlovu, I5 .vi.I926 (R. E. Turner). In B.M.(N.H.). 


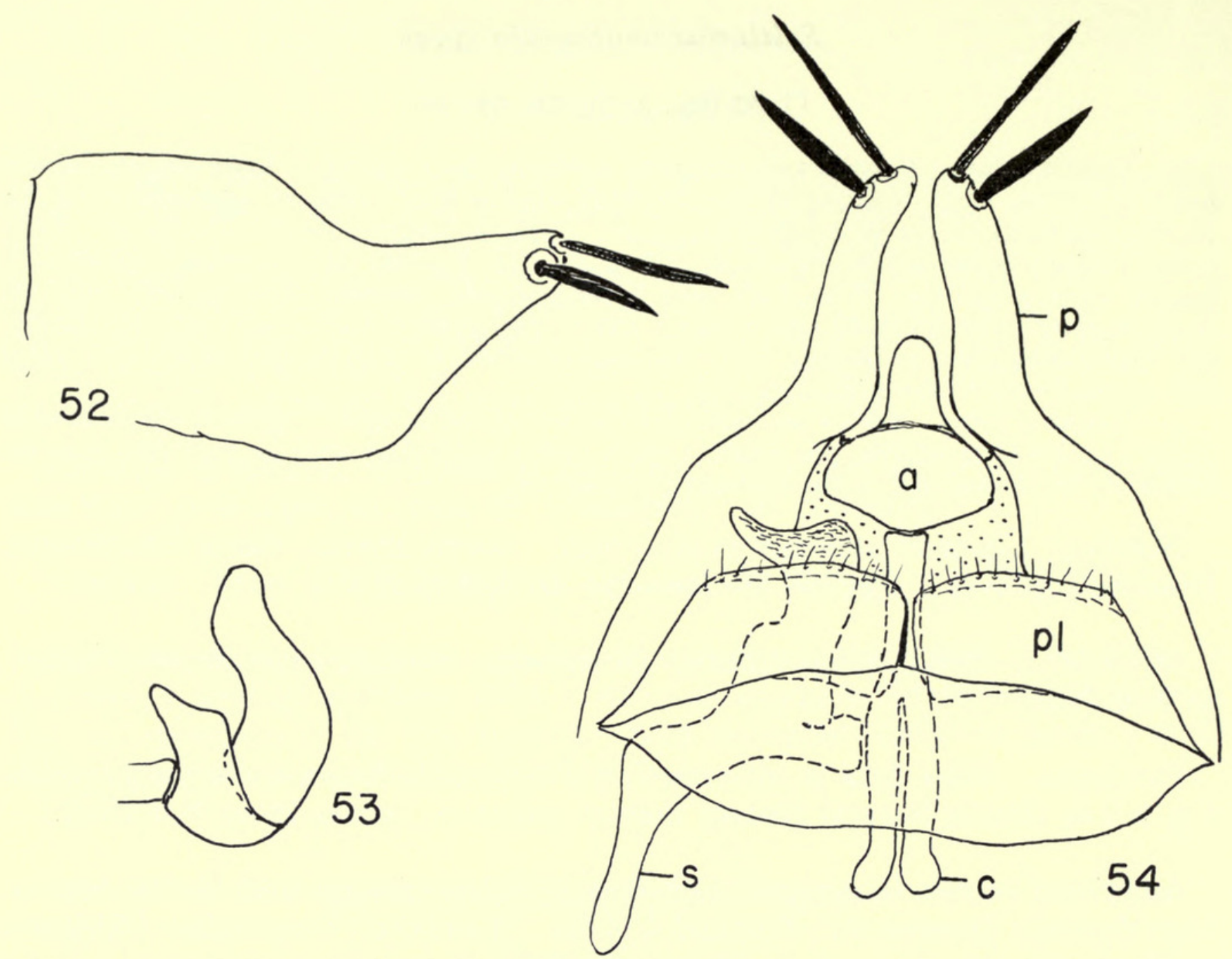

Figs. 52-54. Male genitalia of Exitianus turneri. 52, pygofer; 53, aedeagus, lateral aspect; 54, genital assemblage, ventral aspect (one style omitted). $a$, aedeagus; $c$, connective; $p$, pygofer; $p l$, plate; $s$, style.

Paratypes. Same data as allotype, $3 \hat{o}$ (one without abdomen), $4 \stackrel{+}{ }$, with inclusive dates 9.vi-5.vii.I926; Natal, Kloof, I50o ft., I ㅇ, viii.I926 (R. E. Turner). In B.M.(N.H.), one pair in Illinois Natural History Survey collection.

This species differs from the preceding in the shorter plates and other details of the genitalia, and in the contrasting pale costal margin of the tegmina. In this latter character it resembles the following species, from which it differs in details of the male genitalia and the female eighth sternite.

\section{Exitianus zuluensis sp. $\mathrm{n}$.}

(Text-figs. 6r, 62, 63, 74)

o. Length $5 \mathrm{~mm}$. Colour tawny, the head with an arcuate black band on vertex, and almost equally dark median stripe on the face. Lateral areas of face and legs with dark markings. Tegmina with all veins brown except the costal margin which is cream colour. General 
structure typical for genus. Pygofer (Text-fig. 63) with apical half strongly narrowed and upturned, ending in a single, dorsally-directed heavy black spine (presumably number 2). Plates short, broadly rounded at apex, and without large lateral setae (Text-fig. 6r). Style with apex obliquely truncate, only moderately wide, extending almost to the apex of the plate (Text-fig. 6r). Aedeagus with shaft relatively small, slightly angulate near middle, and narrowed at extreme tip (Text-fig. 62).

․ Length $5.5 \mathrm{~mm}$. Colour and general structure same as male. Eighth segment with transverse posterior margin and with a pair of dark areas, one on each side, just in front of posterior margin (Text-fig. 74).
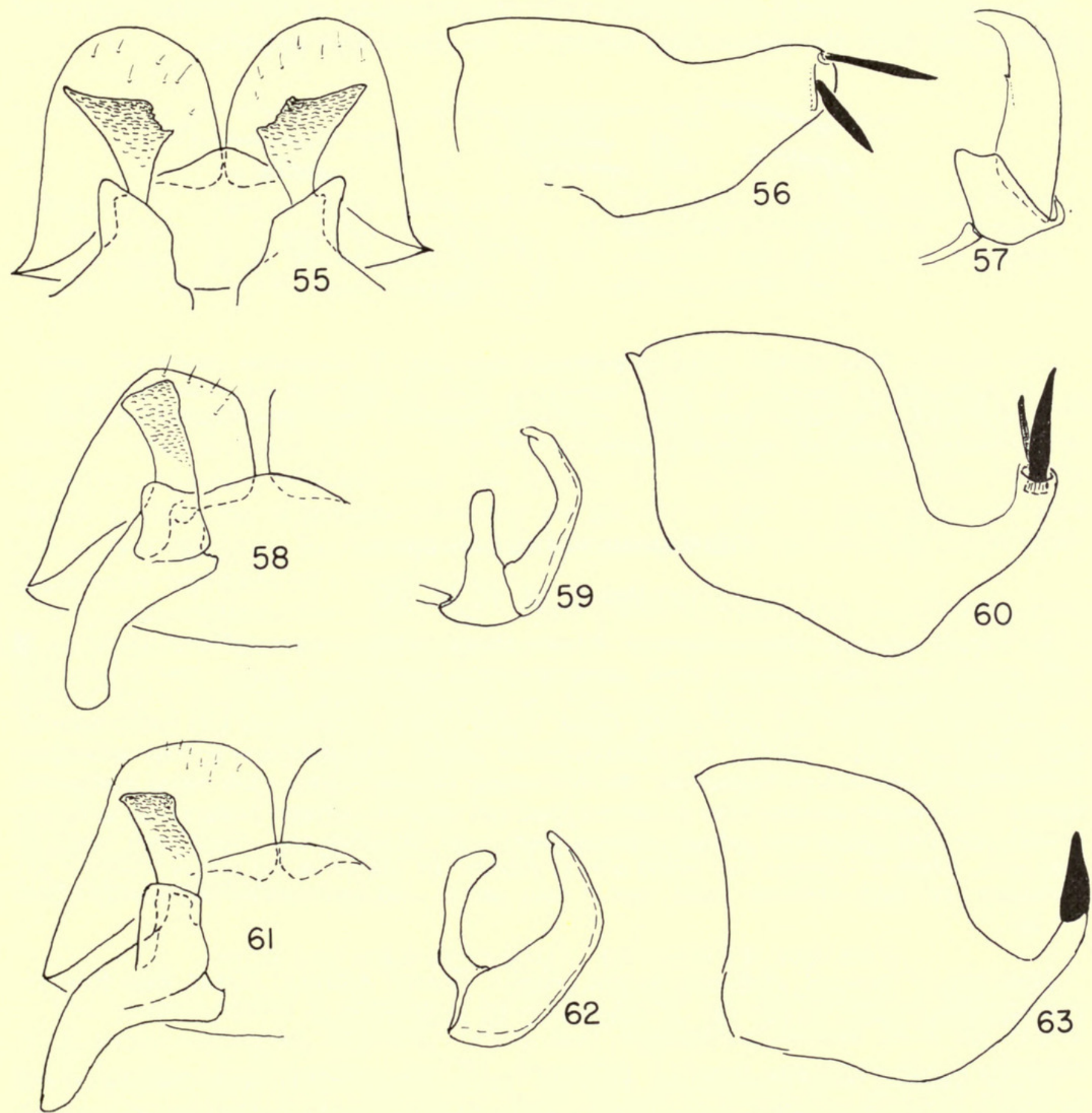

Figs. 55-63. Male genital parts of Exitianus spp. 55, 56, 57, E. okahandia (holotype); 58, 59, 60, E. natalensis (holotype); 6I, 62, 63, E. zuluensis (holotype). 55, 58, 61, style, ventral aspect, with outline of plate shown beneath; $56,60,63$, pygofer; 57,59 , 62 , aedeagus, lateral aspect. 
Holotype $\hat{\sigma}$ (pinned, abdomen in glycerine). South Africa: Zululand, Eshowe, vi. $\operatorname{I926}$ (R. E. Turner). In B.M.(N.H.).

Allotype ㅇ. Same data as holotype. In B.M.(N.H.).

Paratypes. Same data as holotype, 3 ㅇ, 3 without abdomens, with inclusive dates, vi-vii. In B.M.(N.H.), I + in Illinois State Natural History Survey collection.

This species is readily distinguished from the preceding by the peculiar upturned pygofer, and from the species that follows by its pale colour pattern.

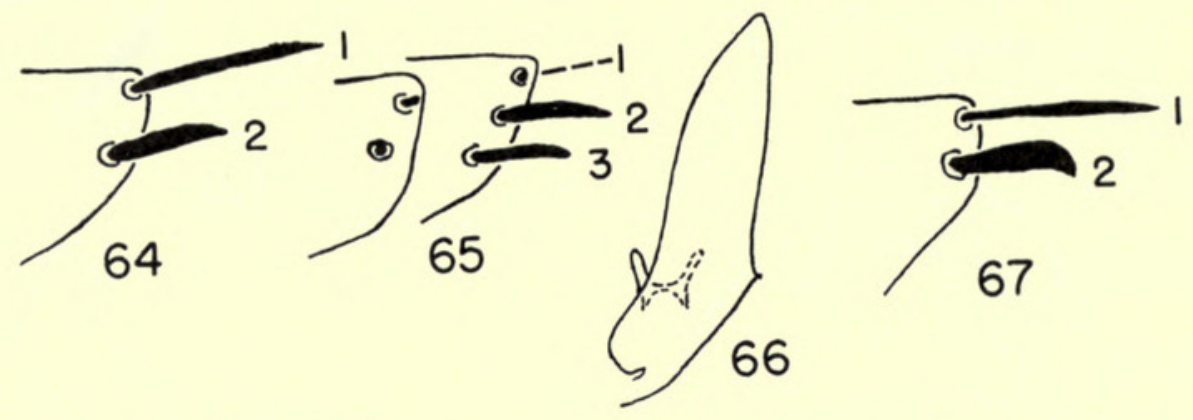

Figs. 64-67. Male genital parts of Exitianus spp. 64, E. attenuatus (holotype), apex of right side of pygofer; 65, same (paratype), apex of right and left sides of pygofer, respectively; 66, same (paratype), quartering posterior view of aedeagal shaft; 67 , E. pondus (holotype), apex of pygofer.

\section{Exitianus natalensis sp. $\mathrm{n}$.}

(Text-figs. 6, 58, 59, 60, 75)

o. Length $4.5 \mathrm{~mm}$. Base colour of dorsum chiefly tawny, vertex of head (Text-fig. 6) with a very wide black arcuate band, pronotum with lateral dark marks, mesonotum with lateral black triangles, face mostly black with tawny enclosed areas, the facial marks running up onto vertex; venter and legs mostly black; tegmina with veins brown and costa contrastingly cream coloured. General structure typical for genus. Pygofer (Text-fig. 6o) with apical half strongly narrowed and upturned, the tip bearing spines I and 2, their bases contiguous, spine I very slender, shorter than 2, spine 2 long and massive. Plates fairly short, and apex broadly rounded, the lateral margin without large setae (Text-fig. 58). Style with relatively long apex, which is truncate and which almost reaches the margin of the plates (Text-fig. $5^{8}$ ). Aedeagus with shaft relatively small, curved near middle, and narrowed at extreme tip (Textfig. 59).

Holotype $\widehat{o}$ (pinned, abdomen in glycerine). South Africa: Natal, Van Reenen, Drakensberg, I-22.i.r927 (R. E. Turner). In B.M.(N.H.).

Three females from Pondoland, Port St. John (B.M.(N.H.)), may belong to this species. In general colour pattern they resemble the male closely, but the pronotum and mesonotum are both much darker and therefore there is a possibility that they may represent another undescribed species. The eighth sternite has the apical margin transverse and uniformly dark coloured (Text-fig. 75). 

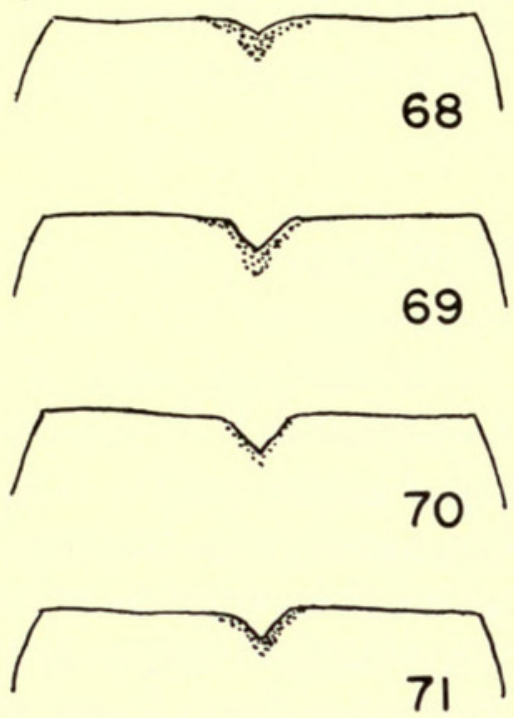
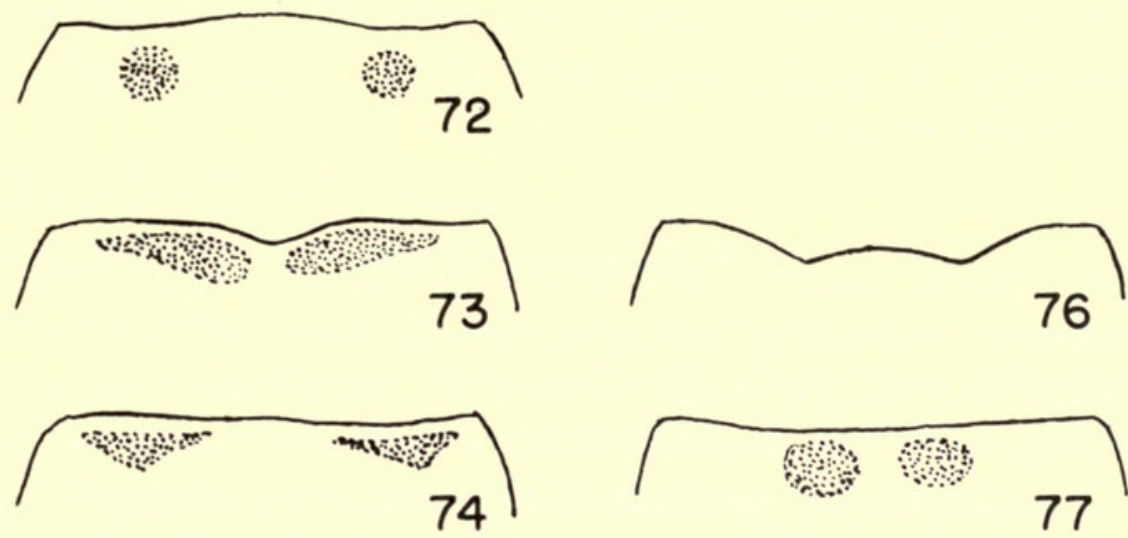

Figs. 68-77. Apex of female eighth sternite. 68, E. plebeius (holotype); 69, E. indicus (holotype); 70, E. capicola (holotype); 7I, E. taeniaticeps (Libya); 72, E. okahandia (allotype); 73, E. turneri (allotype); 74, E. zuluensis (allotype); 75, E. natalensis (Pondoland); 76, E. nanus (holotype); 77, E. africanus (holotype).

UNPLACED SPECIES

Bythoscopus africanus Walker, I85I : 873. Type + seen in B.M.(N.H.), from Sierra Leone (Morgan), 42, 3I. The banded head (much as in Text-fig. Io) and the elongate ovipositor indicate that this species is a member of Exitianus, but the eighth sternite has a straight posterior margin and a pair of large posterior dark spots (Text-fig. 77). No males have been associated with this distinctive specimen, apparently representing a valid species.

Athysanus capicola Stål, I855: 99. Type o seen in the Stockholm Museum, from Meru, Neider. This is a typical member of the taeniaticeps group, with head banded much as in Text-figure 9 and the eighth sternite with a median notch (Text-fig. 70). At present it is impossible to associate this specimen with a recognized species.

Eutettix pallida Evans and selbyi Evans, I938 : I4. Both of these species were described from + types collected in Queensland, and might prove to be additional junior synonyms of plebeius. The leafhopper fauna of Australia is as yet not well enough collected to make undue assumptions concerning the identity of females in this group of species.

\section{SPECIES TRANSFERRED TO OTHER GENERA}

Two species placed in Exitianus by Evans (I966) do not belong in this genusNephotettix contemptus Kirkaldy (I906) and Nephotettix eurytus Kirkaldy (I907), both described from Sydney, N.S.W., Australia. I have examined the o holotypes and an associated $\hat{\sigma}$ of contemptus; they appear to belong to Hybrasil Kirkaldy (I907 : 4I) with brani Kirkaldy as type-species. I have not examined the type of the latter, but the Australian specimens mentioned agree in all but details of individual parts with Linnavuori's (I960) illustrations and description of brani.

The types of Kirkaldy's two Australian species appear identical. The description 
of Carvaka fulvida Evans (I966), described from the Bunya Mountains, Queensland, Australia, is highly suggestive of the same species. The following synonymy is therefore offered:

\section{Hybrasil contemptus (Kirkaldy) comb. n.}

Nephotettix contemptus Kirkaldy, I906 : 332.

Nephotettix eurytus Kirkaldy, I907 : 54. syn. n.

?Carvaka fulvida Evans, I966 : 244. comb. n.

The taxonomic position of Hybrasil is uncertain. Linnavuori (I960) placed it in the Drabescinae and Evans (rg66) his $C$. fulvida in the Selenocephalini (Cicadellinae). Salient features of the genus include the following: Clypellus constricted in middle and expanded at apex; front margin of head with a yellow band defined above and below by a low but sharp carina, and extending from eye to eye; venation typical but with apical two costal crossveins edged with black (as in Fieberiella); plate elongate, the apex narrow and partly membranous, and without large lateral setae; aedeagus with shaft articulated with socket; and ovipositor extending well beyond pygofer (as in Exitianus). Characters of the aedeagal shaft and ovipositor suggest an affinity with the Doraturini.
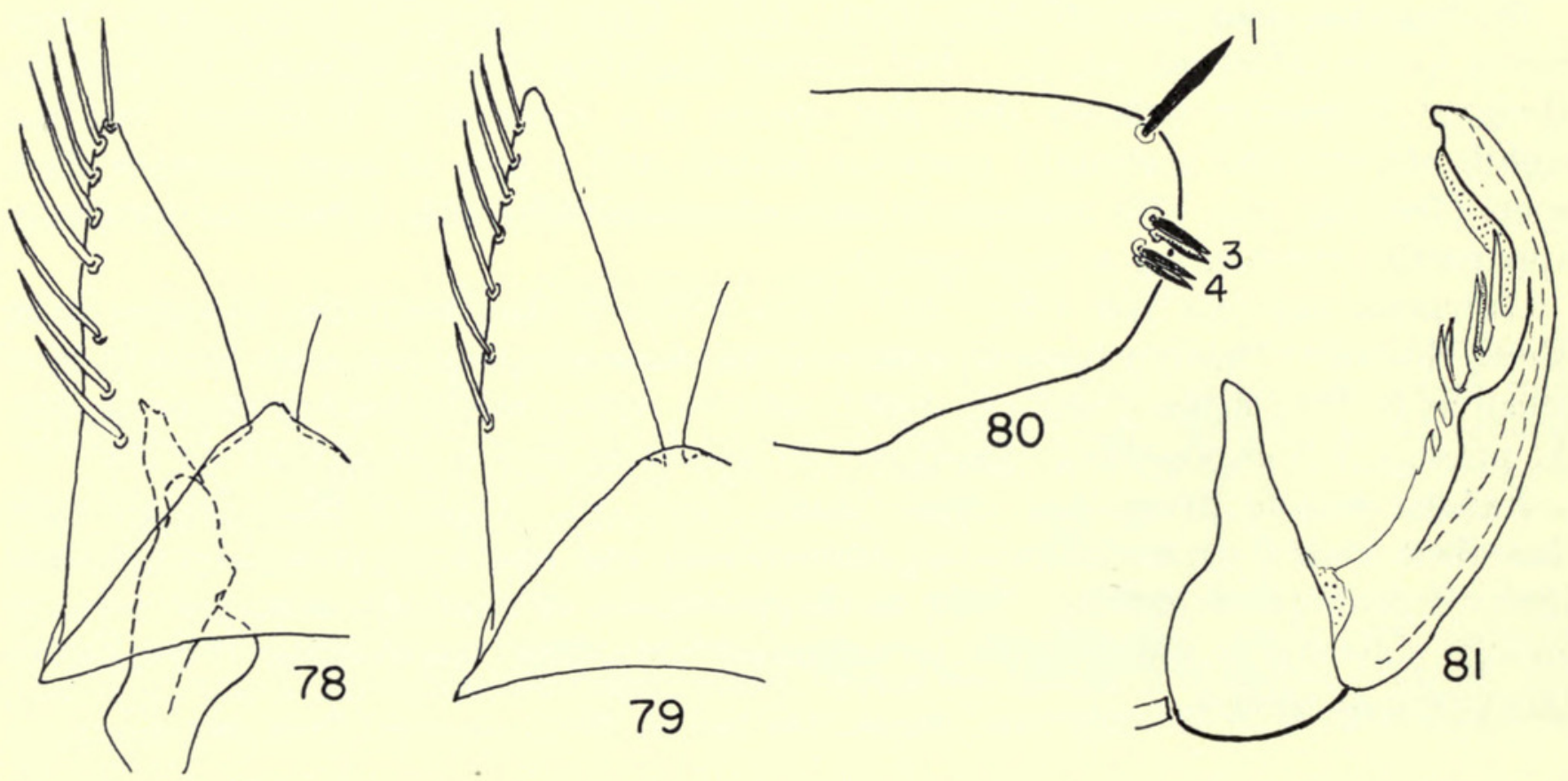

Figs. 78-8I. Male genital parts of leafhoppers. 78, Exitianus greensladei (holotype); 79, 8o, 8I, Nephotettix apicalis (India). 78, 79, plate, ventral aspect; 8o, pygofer; 8I, aedeagus, lateral aspect.

\section{PROBLEMS OF SPECIES RECOGNITION}

On the basis of material that has been examined in this study, there is little problem in establishing satisfactory species-limits in the nanus-group (only one species), the distanti-group (only one species), and the okahandia-group (four species). 
In the obscurinervis and taeniaticeps-groups, however, the situation is far from clear.

\section{OBSCURINERVIS-GROUP}

DeLong \& Hershberger (I947) recognized eleven American species, using the number and juxtaposition of the pygofer spines as their primary bases of species separation, supplemented with colour differences. Linnavuori (I959) uses the same sequence of characters in keying the seven species he recognized from the neotropical region. Oman (I949) questions the value of the number of the pygofer spines as diagnostic characters. He points out that it is not uncommon to find a specimen having unequal numbers of these spines on the left and right sides of the pygofer; I have observed this same phenomenon. It is possible, however, that in some species the relative position of the spines (if present) may represent diagnostic characters.

The real crux of whether or not different entities should be considered as distinct species is whether or not each unit forms a continuing series of populations progressing through time and evolving independently of other genetic lineages (Simpson, I95I; Ross, I962). This is a theoretical concept that can be tested experimentally by crossbreeding if adequate material is available and techniques are known. With Exitianus this experimental avenue is not yet available. The only other highly reliable criterion of the evolutionary distinctness of bisexual phylogenetic lines is whether or not the species segregates occur in the same area, yet remain distinct, with little or no indication of hybridization. In a number of collections of American Exitianus, I have found excellent evidence of different pairs of species occurring together with no sign of intergradation, and I infer from this that most of the described American species are indeed independent phylogenetic lines.

In sorting through these collections, however, another problem has arisen that affects the use of existing keys and descriptions. In almost every species the males are darker than the females and frequently have colour patterns that are more distinctive and more sharply delineated than those of the females. In several instances the differences between the females are negligible whereas the colour patterns of the males are readily differentiated. This is suggestive that the distinctive patterns of the males have evolved as differential display stimuli to which only the correct female normally responds.

This sexual dichromatism complicates the matter of identification, because in existing keys females of several species would key out to the same place, and would run to a different couplet than would the male of the same species. To compound this situation, the shape of the female seventh sternite gives a different visual image depending on the position in which the female died, and use of this character for diagnosis must be attended by extreme caution. Until much more information is available concerning these problems, it seems best to treat all the currently described American species as distinct entities. In Text-fig. 82 the species of the obscurinervis-group have been arranged phylogenetically on a tentative basis using the characters illustrated by DeLong \& Hershberger and by Linnavuori. 


\section{TAENIATICEPS-GROUP}

Of the described species, ootacamundus, kilimanus, coronatus, and greensladei are the only ones having distinctive colour patterns. The remainder have simply a more or less distinct black band across the top of the head. When abdomens of this unicolorous group were cleared and examined, the first thing evident was the striking similarity in all of them of the two pygofer spines: spine I long and slender, somewhat variable in length, and spine 2 short, black, and twisted at the apex. Closer inspection revealed small differences in the shape of the aedeagus, especially its profile. In large series of indicus, this structure has a distinctive broad shape compared with material from islands of the Indian Ocean and from Australia. Material from Asia Minor and North Africa has a distinctive clavate profile with a pronounced step where the two short processes arise; in some specimens from South Africa the aedeagus has essentially the same shape but is more massive; and in collections from the Sudan, unimodal intergrading populations were found that bridged the gap between the Asia Minor and South African types. A long series of material from Madagascar added two other types, one of them similar to the island type and the other differing only slightly from the Asia Minor type. In the first sorting it appeared as if the aedeagus varied randomly and locally in a fashion that almost defied segregation.

On further analysis two points of considerable interest emerged. First, in the three Indian species, indicus, ootacamundus, and coronatus, the aedeagi were of the same type (Text-figs. 25, 28, 30, 3I). Furthermore, in a series of several thousand specimens from Kharagpur there was no indication of intergradation between the plain banding on the head of indicus and the colour patterns distinctive for ootacamundus and coronatus. These circumstances suggest strongly that a line of the taeniaticeps group dispersed into India, evolved the indicus type of aedeagus, and subsequently evolved into three species now differentiated primarily on the basis of head patterns. Second, in Madagascar two types of aedeagi occurred in some of the same localities yet no intergrades were found between them. This suggests that these two morphological types represent true genetic isolation and that two phylogenetic lines are involved.

On the basis of these two different cases, there seems to be a good possibility that the different morphological types of the taeniaticeps group, though sometimes remarkably close, represent distinctive species, and they have been so treated in this paper. Unquestionably a tremendous amount of collecting will be necessary to establish the true nature of these species but until this additional information is forthcoming, the only clear presentation seems to call for a course that may result in some splitting rather than taking the chance of obscuring future leads by lumping.

\section{PHYLOGEN Y}

After the various species of Exitianus had been segregated, the next problem was to decipher the evolutionary sequence and geographic dispersal of the various lineages. As a first step in this evolutionary reconstruction, the species most similar to each other (essentially the groups expressed in the taxonomic analysis) 
were examined for inter-group differences. The various conditions found for any one character were then compared with conditions found in related genera in an effort to determine which were the ancestral and which the derived conditions.

As is true in most inducto-deductive investigations, certain theoretical possibilities are realized when the study commences, and character differences are viewed in their possible evolutionary light from the earliest observations of character differences. The present study was no exception. It was first noticed that in a number of Old World species, pygofer spine 2 was twisted at the apex (Text-fig. 24) and that the profile of the aedeagus was incised at the tip to form a fine curved point (Textfig. 25), whereas in the New World species spine 2 was symmetrical (Text-fig. I9) and the profile of the aedeagus was blunt and little incised (Text-fig. 20). Next it was seen that (I) in one Old World species the pygofer had four, five, or six spines forming an even row (Text-fig. I5), whereas in most New World species there were only three spines with a large space between the two more ventral spines (spine 3 was missing, Text-fig. I9), and (2) in those Old World species with the contorted spine 2, there were only two spines. Finally, another group of African species came to light in which the plates were short and had only very small lateral setae (Textfig. 54), whereas in all other species the plates were long and each had a lateral row of long spines (Text-fig. 78).

A search for related genera with which to compare conditions found in Exitianus soon divulged the information that (I) the genus Nephotettix was the only demonstrable close relative of Exitianus, (2) the genera Gillettiella Osborn, Stivellus Osborn \& Ball, Doratura Sahlberg, and other genera possessing a long ovipositor were components of the same tribal unit (Doraturini) as Exitianus, and (3) many genera related to Athysanus Burmeister and Recilia Edwards belonged to the same large branch of the leafhoppers.

In Nephotettix the pygofer has a set of apical dark spines much like those in Exitianus. The dorsal spine (Text-fig. 80) seems to correspond with spine I of Exitianus; the lower four spines seem to correspond with spines 3 and 4 of Exitianus but are each represented by a pair of spines; spine 2 seems to be missing. The plate is long and triangular, bearing lateral long setae (Text-fig. 79), exactly like those of Exitianus. The aedeagus has the same parts as in Exitianus, but the shaft is highly ornamented (Text-fig. 8I). Nephotettix, however, has an unusual opaque green ground colour and a sharply carinate forehead, and thus would appear to be a separate branch arising before the evolution of Exitianus as it is now represented. It seems reasonable to suppose that Nephotettix and Exitianus arose from a common ancestor that was remarkably like the nanus group of Exitianus, but probably having a more cryptic colour pattern similar to that found in many other grass-inhabiting leafhoppers.

Comparing the conditions exhibited by Exitianus and Nephotettix with those found in other leafhopper genera, it was evident that (I) the long plates with lateral spines represented the ancestral condition of this structure within Exitianus, and the short plates represented a derived condition; (2) the larger number of pygofer spines was the ancestral condition for the structures, the reduced number the derived condition; (3) the symmetrical pygofer spine 2 was the ancestral condition, the twisted 
spine 2 the derived condition; and (4) the blunt aedeagus was the ancestral condition for this structure, the incised and pointed type the derived condition.

From these considerations of ancestral and derived conditions, it is most likely that the ancestor of Exitianus (Ancestor I in Text-fig. 82) possessed triangular setose plates, at least four or five pygofer spines, all symmetrical, and a blunt aedeagus. These conditions are exemplified by nanus, which would therefore seem to be the living representative still bearing this archaic combination of ancestral characters. The remainder of the species have lost either spine 3 or spines 3,4 , and 5 . It is therefore reasonable to suppose that Ancestor I gave rise to a lineage losing spine 3 and represented by Ancestor 2. Most of the native American species comprising the obscurinervis group represent this condition (Text-figs. I9, 20).

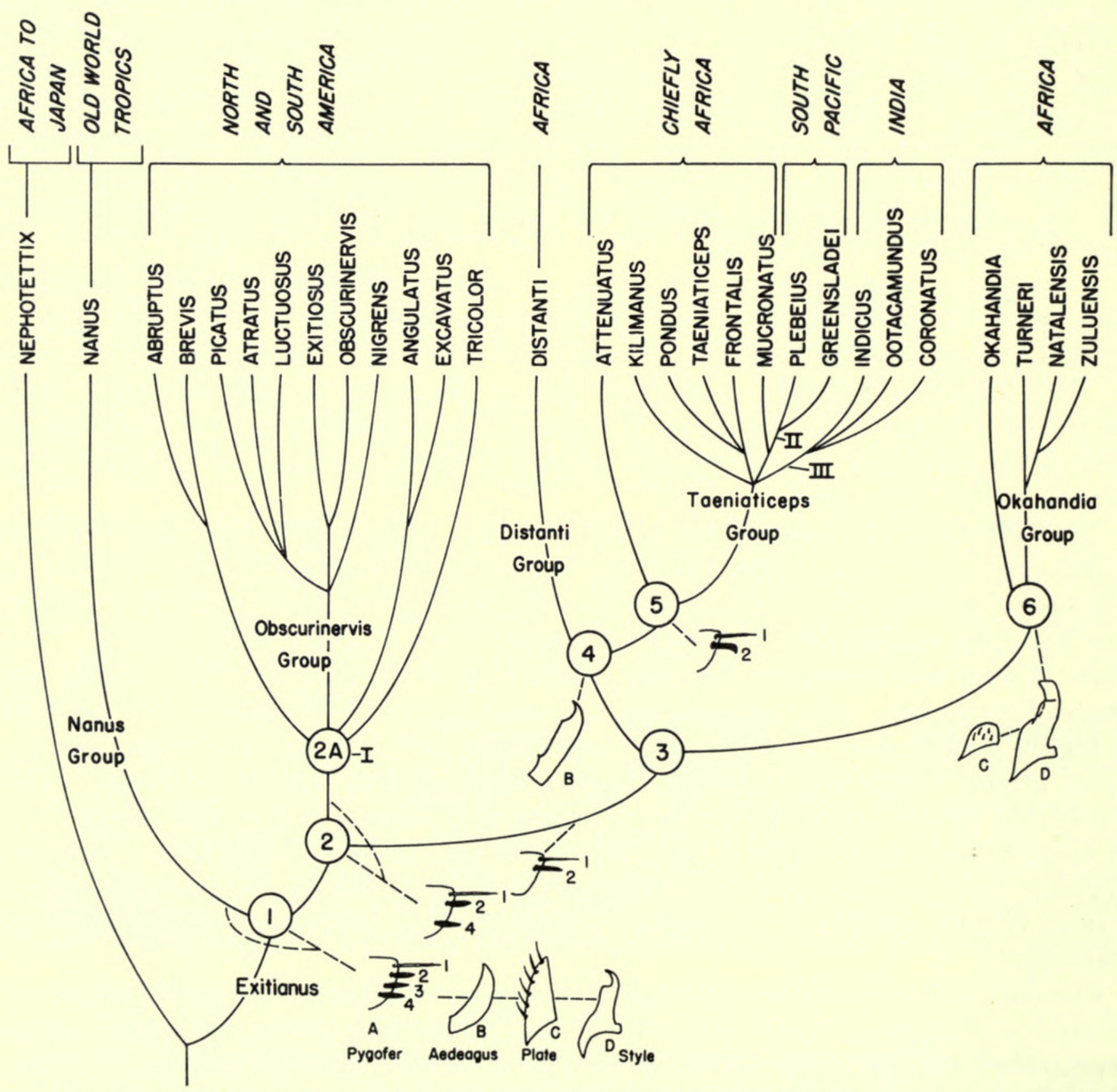

FIG. 82. Proposed family tree of Exitianus. Arabic numerals refer to putative ancestral forms explained in text. Roman numerals indicate postulated past dispersals as follows: I, Africa to New World; II, Africa to South Pacific; III, Africa to India. 
If one adds together the primitive conditions found in the remainder of the species (all native to the Old World), the result is a form having triangular setose plates, blunt aedeagus, and only two aedeagal spines. This ancestral form (Ancestor 3 of Text-fig. 82) differs from Ancestor 2 only in lacking pygofer spine 4. Ancestor 3 apparently gave rise to two lineages. In one of these, represented by Ancestors 4 and 5 , the plates did not change but the aedeagus became incised and pointed at the tip; in the other lineage, represented by Ancestor 6, the aedeagus did not change but the plates became short and their setae greatly reduced. In Ancestor 4, pygofer spine 2 was probably still symmetrical. Such a stage may be represented by distanti, although in this species spine 2 is more elongate and in this respect is specialized over the theoretical structure of Ancestor 4. In addition to distanti, Ancestor 4 gave rise to Ancestor 5 in which pygofer spine 2 became twisted at the apex.

From Ancestor 5 evolved the species of the taeniaticeps group. The most primitive species of the group is attenuatus, in which pygofer spine 2 is only slightly contorted (Text-figs. 64, 65) and appears to represent a transitional condition leading to the more extreme asymmetry of this spine found in all other members of the taeniaticeps group. Nine of the remaining ten species of the group are readily grouped into three complexes. In the three species indicus, ootacamundus, and coronatus the aedeagal shaft is unusually short and broad (Text-figs. 25, 28, 30, 3I). In pondus, taeniaticeps, and frontalis the dorsal points of the shaft are situated on a steplike sinuation of the profile (Text-figs. 34-36, 39-42, 47). In mucronatus, plebeius, and greensladei the basal profile of the shaft has no such basal sinuation (Text-figs. 43-46, 48-5I). At present there seems to be no logical basis for knowing the exact affinities of these three complexes, hence in Text-fig. 82 their origin is depicted as a trichotomy. The tenth species, kilimanus, can at present be placed in the family tree only tentatively because of a lack of knowledge of the internal structures.

Ancestor 6, the 'short plate' offshoot of Ancestor 3, is represented by the okahandia group. In the species okahandia, the wing colour and head proportions are similar to those of paler species in the other groups; in turneri, natalensis, and zuluensis the tegmen or front wing has a fairly broad whitish costal stripe running the full length of the wing. These three apparently represent an offshoot of Ancestor 6 in which this character became established. In both okahandia and turneri the shape of the pygofer and the position of its apical spines is typical of other members of the genus, hence this condition must have been present in Ancestor 6 also. From this we can infer that the broad, flared styles found in these two species were also present in Ancestor 6. From the lineage leading to turneri there arose a branch in which the apex of the styles became elongate (Text-figs. 58,6I) and the apex of the pygofer became narrowed and upturned, pygofer spine 2 became greatly enlarged and spine I reduced (Text-fig. 60), ultimately lost in zuluensis (Text-fig. 63). Judging by the character by character changes that appear to characterize much of insect evolution, it is a reasonable prediction that additional collecting will bring to light an ancestral form having either the elongate style or the highly modified pygofer, but not both, now found in natalensis and zuluensis. Such a form would give us information as to which of these character changes evolved first. 
When geographic distribution is compared with the postulated family tree of Nephotettix and Exitianus (Text-fig. 82), it is apparent that the genus is tropical or subtropical (except for the American exitiosus), and therefore has in all likelihood been restricted to the tropics and subtropics during almost all of its evolution. It is further apparent that the evolution of the entire group occurred in the Old World tropics with the exception of the obscurinervis group, which evolved in North and South America. Linnavuori recorded several South American specimens as taeniaticeps, which I am presuming represent a transport by man. If this is indeed the case, then the only natural intercontinental dispersal of which we have record was an Old World-to-New World dispersal of Ancestor 2.

Considering only the Old World records, the simplest explanation is reached by assuming that the genus evolved primarily in Africa. The indicus branch of Ancestor 5 apparently is a moderately old dispersal from Africa to southeastern Asia. The plebeius-greensladei branch of Ancestor 5 represents another dispersal eastward to Australia and the South Pacific. The present day widespread distribution of nanus and frontalis could be the result of natural dispersal. This seems especially likely with regard to nanus.

This probable African evolution of the genus poses a problem with regard to probably the oldest intercontinental dispersal of the genus, that of Ancestor 2 to the Americas, represented by Ancestor $2 \mathrm{~A}$ in Text-fig. 82. If this occurred sufficiently long ago, possibly in the Eocene or early Oligocene, it would be simple to postulate an overland dispersal through subtropical climates across the Bering bridge. If this did happen it is puzzling that a branch of the genus comparable to the obscurinervis group did not evolve and persist in southeastern Asia.

A second possible solution is that Ancestor 2 was carried from Africa to South America by wind dispersal. This explanation seems more probable because of the discovery of long-distance migrations of much smaller leafhoppers in moving masses of warm, moist air. If this were the case, it is remarkable that apparently only one such dispersal occurred and became established during the entire evolution of the genus. Dispersal patterns of grass subgenera would indicate that satisfactory grass hosts for Exitianus have been present in the Americas for at least the probable period of Exitianus evolution.

A third explanation is that Ancestor 2 was a species with an unusually wide ecological tolerance, much like that of present day Nearctic exitiosus, that the species was able to cross into North America through warm temperate rather than tropical climates, and that subsequently, for one reason or another, the range of the wicicspread species became fragmented into Old and New World segments that eventually lost their ability to live in temperate climates.

A better insight into the circumstances surrounding the American dispersal of Exitianus may come when we understand more about the dispersal of grassland communities as a whole.

\section{ACKNOWLEDGMENTS}

I have received much technical and advisory help in these studies from Dr. W. J. Knight and other officers of the British Museum, Dr. Alfred Orian, Mauritius Depart- 
ment of Agriculture, and Dr. J. P. Kramer, U.S. Department of Agriculture. To Mrs. Nell Miles, Urbana, Ill., Dr. F. R. Steggerda, University of Illinois, Dr. H. G. Walker, Los Angeles County Museum, Dr. L. W. Quate, University of Hawaii, Dr. D. H. Murphy, University of Singapore, Dr. J. W. Evans, Australian Museum, Dr. G. C. Sanderson, Illinois Natural History Survey, and Mrs. N. J. Kemp, Australia, I am indebted for Old World material collected or loaned, and especially to Dr. L. T. Gressitt and his associates, B.P. Bishop Museum, for the loan of type material. To the officers of the Stockholm Museum I am much indebted for courtesies accorded on a visit to their Museum.

This study has also been supported by a research grant from the U.S. National Science Foundation and in many ways by the Illinois Natural History Survey.

REFERENCES

BALl, E. D. 1929. A supplemental revision of the genus Athysanus in North America (Homoptera : Cicadellidae). Trans. Am. ent. Soc. 55 : I-8I.

Bergevin, E. DE. I925. Description d'une nouvelle espèce d'Athysanus suceur de sang humain de l'extrême Sud Algérien (Hémiptère-Homoptère, Jassidae). Archs Inst. Pasteur Algér. $3: 42-44,5$ figs.

Delong, D. M. \& Hershberger, R. V. i947. The genus Exitianus in North America including Mexico. Ohio J. Sci. 47 : 107-1 I6, 2 pls.

Distant, W. L. I908. The Fauna of British India including Ceylon and Burma. RhynchotaHomoptera. 4, 50I pp., 282 figs. London.

I909. 'Sealark' Rhynchota. Trans. Linn. Soc. Lond. Zool. 13 (2) : 29-47, 4 pls.

- I9I7. Rhynchota. Part II: Suborder Homoptera. The Percy Sladen Trust Expedition to the Indian Ocean in 1905, under the leadership of Mr. J. Stanley Gardiner, M.A. Trans. Linn. Soc. Lond. Zool. $17: 273-322$, pls. 49-5I; text-figs. I-I 7.

I918. The Fauna of British India, including Ceylon and Burma. Rhynchota. Homoptera: Appendix. Heteroptera: Addenda. 7 : i-vii, I-2 I0, 90 pls. London.

Evans, J. W. I938. Australian leafhoppers (Homoptera, Jassoidea). Part VIII. Pap. Proc. R. Soc. Tasm. 1938 : I-I8, 3 pls.

1966. The leafhoppers and froghoppers of Australia and New Zealand (Homoptera : Cicadelloidea and Cercopoidea). Mem. Aust. Mus. 12:347, 48 figs.

Ishinara, T. I954. Homopterous notes. Scient. Rep. Matsuyama agric. Coll. 14 : I-28, I7 figs.

Jасові, A. г91о. Wissenschaftliche Ergebnisse der Schwedischen Zoologischen Expedition nach dem Kilimandjaro, dem Meru und den Umgebenden Massaisteppen Deutsch-Ostafrikas I905-1906. Unter Leitung von Prof. Dr. Yngve Sjöstedt. Herausgegeben mit Unterstützung von der konigl. Schwedischen Akad. der Wiss. I2. Hemiptera. 7 Homoptera. 2: 97-I36, pls. I-2, figs. A-N. Stockholm.

Kirschbaum, C. L. I868. Die Cicadinen der Gegend von Wiesbaden und Frankfurt a. M. nebst einer Anzahl neuer oder schwer zu unterscheidender Arten aus anderen Gegenden Europa's. Jb. nassau ver. Naturk. 21-22 : I-202.

Kirkaldy, G. W. I906. Leafhoppers and their natural enemies. Pt. IX, Leafhoppers. Hemiptera. Bull. Div. Ent. Hawaiian Sug. Plrs' Ass. Exp. Stn. 1 (9) : 27I-479, pls. 2 I-32. 1907. Leafhoppers-supplement. (Hemiptera.) Bull. Div. Ent. Hawaiian Sug. Plrs' Ass. Exp. Stn. 3 : I-I86, pls. I-20.

Linnavuori, R. I959. Revision of the neotropical Deltocephalinae and some related subfamilies (Homoptera). Suomal. eläin-ja kasvit. Seur. van. eläin. Julk: I-370, I44 figs. I960. Cicadellidae (Homoptera, Auchenorrhyncha) of Fiji. Acta ent. fenn. 15: I-7I 22 figs. 
Matsumura, S. igi4. Die Jassinen und einige neue Acocephalinen Japans. J. Sapporo agric. Coll. 5 : 165-240, figs. I-I2.

Metcalf, Z. P. I946. Homoptera. Fulgoroidea and Jassoidea of Guam. Bull. Bernice P. Bishop Mus. 189 : 105-148, figs. I-30.

Motschulsky, V. I. DE. I863. Essai d'un catalogue des insectes de l'ŝle Ceylan. Byull. mosk. Obshch. Ispȳt. Prir. 36 : I-I 53, illus. (94-I I3).

Oman, P. W. I949. The Nearctic leafhoppers (Homoptera : Cicadellidae). A generic classification and check list. Mem. ent. Soc. Wash. 3 : I-253, pls. I-44.

Ribaut, H. I952. Faune Fr. Homoptères Auchénorhynques. II (Jassidae). 57: I-474, figs. I-I2I2. Paris.

Ross, H. H. I962. A Synthesis of Evolutionary Theory. 387 pp., I46 figs. Englewood Cliffs, New Jersey.

Simpson, G. G. I95I. The Species concept. Evolution 5:285-298, 4 figs.

STÅL, C. I855. Hemiptera från Kafferlandet. Öfvers. K. VetenskAkad. Förh. 12: 89-ıoo.

WALKER, F. I851. List of the specimens of Homopterous insects in the collection of the British Museum 3 : 637-907. London.

Zachvatkin, A. A. I935. Notes on the Homoptera-Cicadina of Jemen. Uchen. Zap. mosk. gos. Univ. 4 : IO6-II5.

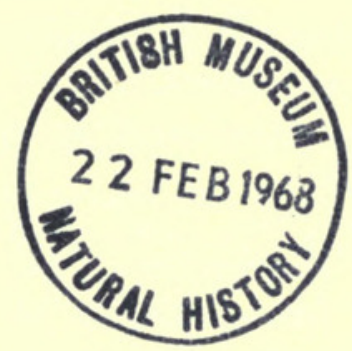




\section{$2 \mathrm{BHL}$ Biodiversity Heritage Library}

Ross, Herbert H. 1968. "The evolution and dispersal of the grassland leafhopper Exitianus with keys to the Old World species." Bulletin of the British Museum (Natural History) Entomology 22, 1-30.

https://doi.org/10.5962/bhl.part.9949.

View This Item Online: https://www.biodiversitylibrary.org/item/19410

DOI: https://doi.org/10.5962/bhl.part.9949

Permalink: https://www.biodiversitylibrary.org/partpdf/9949

\section{Holding Institution}

Natural History Museum Library, London

\section{Sponsored by}

Natural History Museum Library, London

\section{Copyright \& Reuse}

Copyright Status: In copyright. Digitized with the permission of the rights holder.

Rights Holder: The Trustees of the Natural History Museum, London

License: http://creativecommons.org/licenses/by-nc-sa/4.0/

Rights: http://biodiversitylibrary.org/permissions

This document was created from content at the Biodiversity Heritage Library, the world's largest open access digital library for biodiversity literature and archives. Visit BHL at https://www.biodiversitylibrary.org. 